\title{
Climate change/variability and hydrological modelling studies in Zimbabwe: a review of progress and knowledge gaps
}

\author{
Auther Maviza ${ }^{1,2}\left(\mathbb{D} \cdot\right.$ Fethi Ahmed ${ }^{2}$
}

Received: 23 July 2020 / Accepted: 17 March 2021 / Published online: 12 April 2021

(c) The Author(s) $2021 \quad$ OPEN

\begin{abstract}
This paper reviews developments in climate science and hydrological modelling studies in Zimbabwe over the past 29 years in an effort to expose knowledge gaps within this research domain. We initially give a global and regional overview and then follow a systematic thematic approach in reviewing specifically online published, peer-reviewed journal articles on climate change/variability and hydrological modelling in Zimbabwe. The state and progress towards advanced integrated climate and hydrological modelling research are assessed, tracking benchmarks in the research methodologies (tools and techniques) used therein including geographic information systems and remote sensing. We present descriptive summaries of key findings, highlighting the main study themes (categories) and general conclusions arising from these studies while examining their implications for future climate and hydrological modelling research in Zimbabwe. Challenges associated with climate and hydrological modelling research in Zimbabwe are also briefly discussed and the main knowledge gaps in terms of research scope and methodologies employed in the reviewed studies also exposed. We conclude by presenting plausible potential areas of focus in updating and advancing scientific knowledge to better understand the climate-land use-hydrology nexus in Zimbabwe. While this paper is primarily relevant for researchers, the general findings are also important for policy-makers since it exposes potential areas for policy intervention or agenda setting in as far as climate and hydrology science research is concerned so as to effectively address pertinent questions in this domain in Zimbabwe.
\end{abstract}

Keywords Zimbabwe $\cdot$ Climate change $\cdot$ Hydrology $\cdot$ Modelling $\cdot$ GIS $\cdot$ Remote sensing

Mathematics Subject Classification $86 \mathrm{~A} 08 \cdot 86 \mathrm{~A} 05$

JEL Classification AR14·Q24·Q25

\section{Introduction}

A review of global climate changes since 1700 has revealed that over the centuries, twenty climatic events covering continental-scale temperature fluctuations, hydroclimatic anomalies, stratospheric perturbations and general atmospheric composition changes have occurred, impacting millions of people in many ways [1-4]. As such, understanding and predicting these inter-annual, and multi-decadal variations and changes in climate and the resultant impacts has become a critical and active area of research globally over the decades. Several studies have been undertaken to quantify the extent of impacts and the dynamics (in space and time) of climate change on

$\triangle$ Auther Maviza, auther.maviza@nust.ac.zw | ${ }^{1}$ Department of Environmental Science and Health, Faculty of Applied Sciences, National University of Science and Technology, Corner Cecil Avenue and Gwanda Road, Ascot, Bulawayo, Zimbabwe. ${ }^{2}$ School of Geography, Archaeology and Environmental Studies, University of Witwatersrand, 1 Jan Smuts Avenue, Braamfontein, Johannesburg, South Africa. 
water resources [5-11], food security [12-16], ecosystems [17-20], energy, and human health [21-23]. All these studies have revealed that climate change is a significant factor to consider in holistic planning for community resilience and adaption, fostering global progress towards achieving the United Nations Sustainable Development Goals (UN SDGs), Agenda 2030 and Paris Agreement goals [24-27]. These impacts are expected to vary in different countries in various regions of the world considering the differences in climate-sensitivity of vulnerable populations with likely increases in poverty and inequities as a consequence of climate change especially in developing countries $[28,29]$.

In developing countries in Africa for example, where the impacts of climate system changes are predicted to be manifest in more uncertain terms [30-37], expanding knowledge in this domain has become more pertinent hence the steady developments in research therein. In Southern Africa, studies also indicate a continued high climate variability $[35,38,39]$ marked by recurrent droughts and floods in the future [40-43], notwithstanding the uncertainties in these studies. The scope of these studies has been diverse, covering various focus areas such as climate modelling [44-47], hydrological impacts [48-51] and other general impact studies [52-55].

Despite all the advances made in the aforementioned studies, knowledge gaps are well acknowledged particularly considering the inherent uncertainties in the new developments in climate science/modelling and climate impact assessment techniques [56]. Tools and approaches are now available and more are being developed that allow for a better understanding and characterisation of the implications of climate change and variability to assist in better climate risk management strategy development $[57,58]$ in developing countries such as Zimbabwe. As such, the scientific community within and outside Zimbabwe has, over the past decades, been able to exploit various tools and techniques to generate new knowledge pertaining to the local climate dynamics and impacts to better guide decision making specifically tailored to the local needs. One key area of focus has been the implications of climate change on water resources/hydrological systems, considering that a significant part of Zimbabwe is generally semi-arid in nature.

Furthermore, considering the acknowledgement of spatio-temporal land use and land cover change (LULCC) as an important factor (with both direct and indirect implications) on hydrological systems [59-64], attempts have also been made to explore the climate-LULCC-hydrology interlinkages using coupled systems approaches in various studies globally [65-69]. All these studies indicate a wide scope of themes covered over the years as earlier mentioned and as such, it becomes important to explore and characterise these studies in a more systematic manner so as to better appreciate the advances made so far and identify the knowledge gaps therein. Very few known studies, e.g. Bhatasara [70] and Brazier [71], have attempted to extensively review climate change research in Zimbabwe albeit from a Foucauldian discourse perspective and general impacts and mitigation sense, respectively. With regards to climate-hydrological modelling studies, no known study has reviewed such; hence in this paper we attempt to expand the scope of review in these areas by presenting key research developments in climate science and hydrological modelling in Zimbabwe over the past three decades. The ultimate goal is to expose knowledge gaps, i.e. possible areas for further research in this domain in Zimbabwe.

\section{Methods}

We adopted a systematic search for relevant peerreviewed literature from a range of databases searched using Google Scholar (GS) search engine leveraging its strength of cataloguing 100 million records of academic literature and most importantly being able to competently find potentially valuable grey literature (i.e. articles published by non-commercial academic publishers) [72]. We also utilised EBSCO Discovery Service within the University of Witwatersrand's e-library resources to augment the GS search and to widen the scope and depth of our search. Our search was limited to papers published in English between 1990 and 2019 covering climate change and variability dynamics, climate modelling and hydrological modelling covering briefly the global, continental, regional perspectives and then more extensively the Zimbabwean context. The literature search inclusion and exclusion criteria are summarised in Table 1. Thematic analysis adapting and integrating the approaches of Perkins et al. [73] and Nichols et al. [74] was used in assessing the content of the selected journal articles and categorising them according the study keywords and their dominant/predominant focus area/theme, e.g. general climate trends study, climate impact and climate modelling. Climate impact studies were further categorised according to impact areas, e.g. agricultural impacts, livelihood impacts, ecological impacts, hydrological impacts and energy impacts. We also identified and categorised studies specifically integrating hydrological modelling and climate modelling leveraging geographic information systems (GIS) and remote sensing (RS) techniques. The various hydrological and climate modelling techniques/tools used in the selected studies were also assessed. General descriptive statistics (frequencies and proportions), Tables and Pie charts were used to present the findings of the study. Figure 1 summarises the main steps of our study methodology. However, it is 
Table 1 Literature inclusion and exclusion criteria summary used to select articles covered in the review

\begin{tabular}{lc}
\hline Inclusion criteria & Exclusion criteria \\
\hline $\begin{array}{l}\text { Published, peer-reviewed academic journal articles on global, continental and regional scope } \\
\text { on climate change and variability (trends) and hydrology }\end{array}$ & Unpublished, non-peer-reviewed materials \\
$\begin{array}{l}\text { Published, peer-reviewed academic journal articles on climate change and variability, climate } \\
\text { and hydrological modelling in general and specifically in Zimbabwe }\end{array}$ & $\begin{array}{c}\text { News articles, Unpublished thesis, Unof- } \\
\text { ficial reports, Blog sites materials } \\
\text { Old publication (>15 years) for global, } \\
\text { Peer-reviewed journal articles on climate impacts in general and local (Zimbabwe) }\end{array}$ \\
$\begin{array}{l}\text { Peer-reviewed journal articles published in English language from 1990 (for Zimbabwe scope) } \\
\text { Published book sections/chapters, ebooks, Reports (used in discussion only) }\end{array}$ & $\begin{array}{c}\text { Non-English language publications } \\
\text { General, non-scientific reports }\end{array}$ \\
\hline
\end{tabular}

Fig. 1 Methodology flow diagram showing the main steps of the study approach. ( Adapted from Nichols et al. [74])

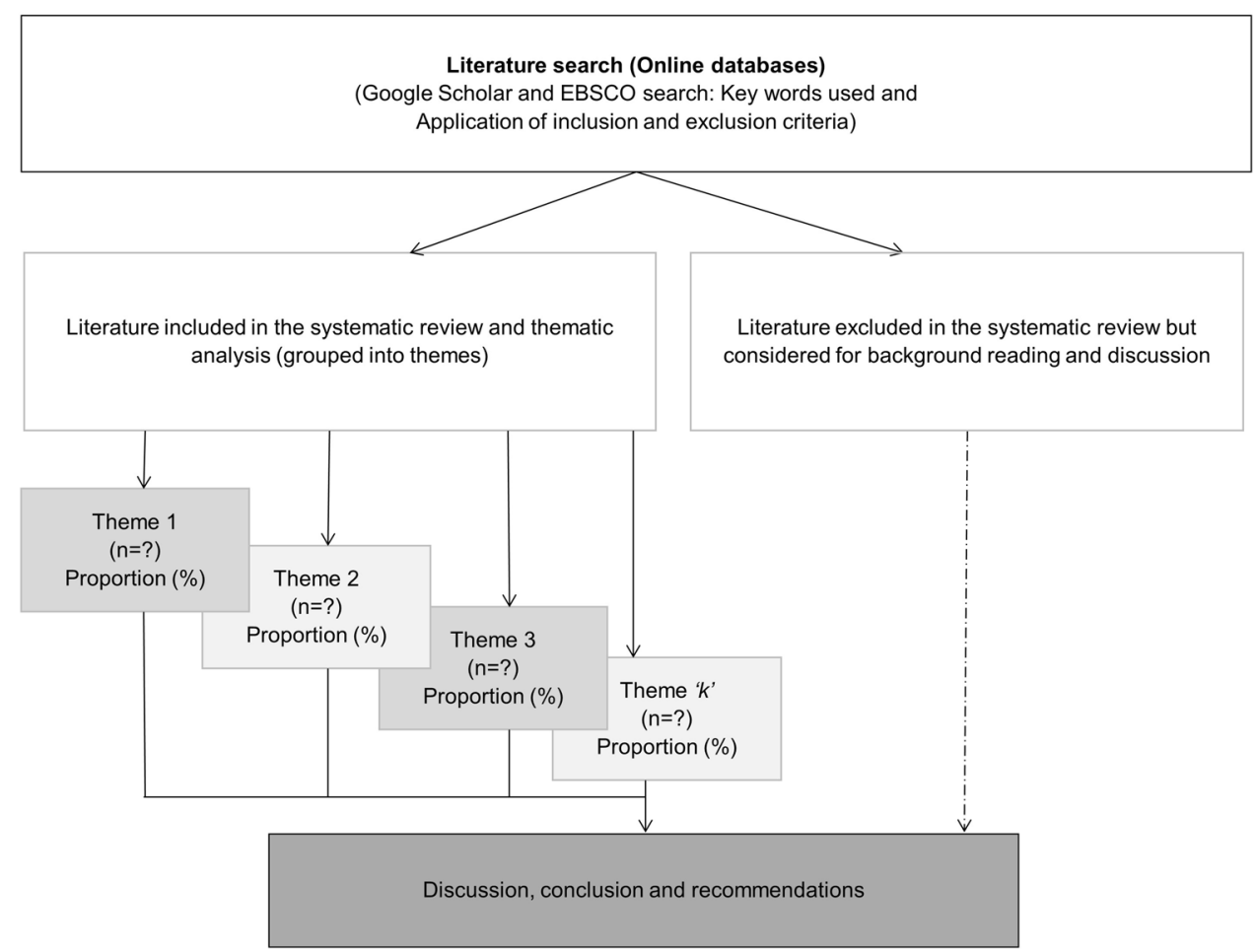

3 Results and discussion

\subsection{Climate change/variability}

\subsubsection{Global and regional climate change/variability studies: a brief overview}

Climate change refers to a statistically significant variation in either the mean state of the climate or in its variability, persisting for an extended period (typically decades or longer) due to natural internal processes or external forcings, or persistent anthropogenic changes in the composition of the atmosphere or in land use [75]. Most scientists have, however, settled to use the term climate change to refer primarily to observed and predicted changes mainly as a result of human activities $[53$, 


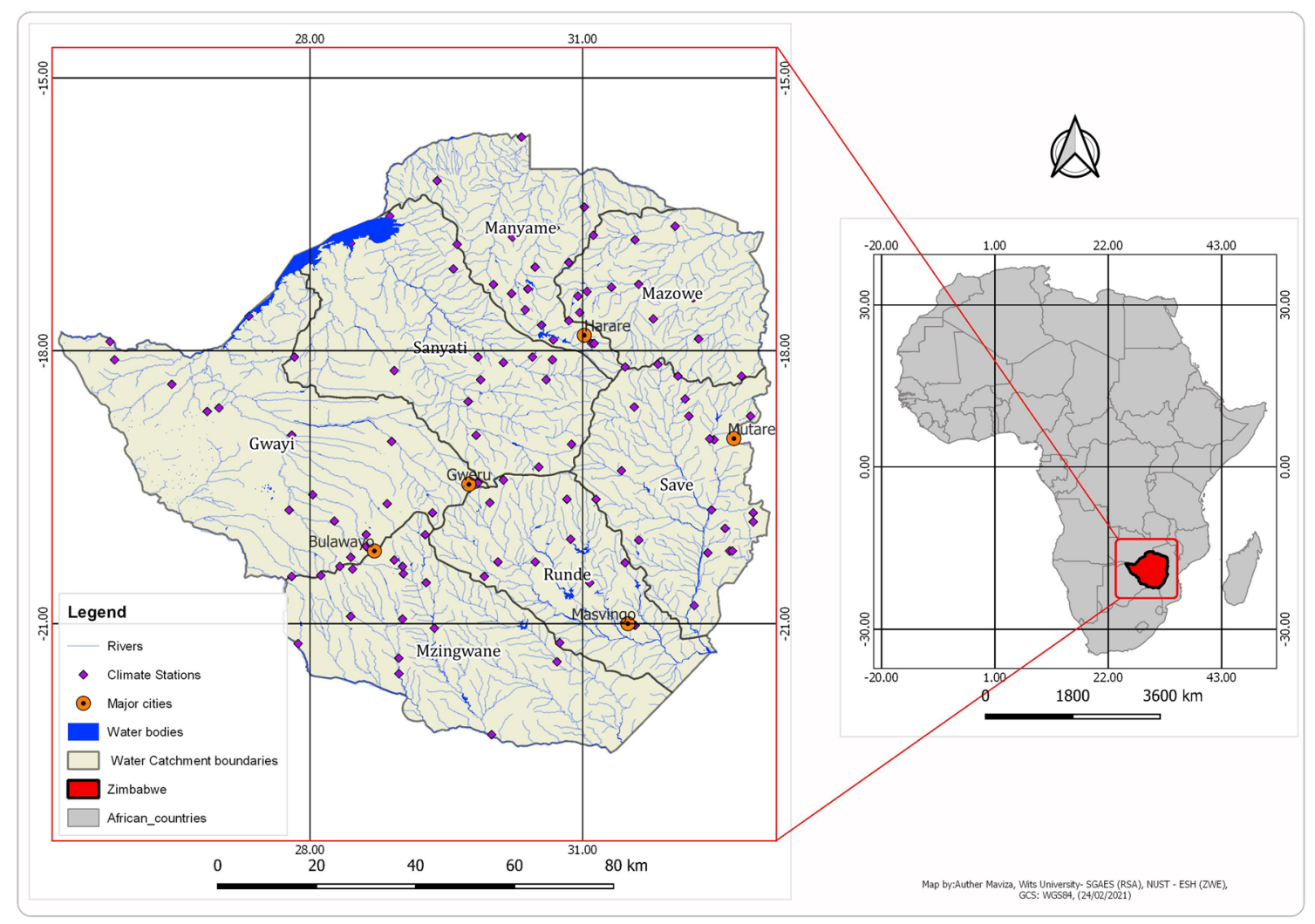

Fig. 2 Map showing location of Zimbabwe (study area) relative to other countries in Africa

76-78], though others suggest that climate changes are a result of natural cycles [3]. Over the years, the debate has evolved to include populist ideologies charged with political undertones [79-83], while some have presented alternative views in what has been termed the 'climate change hiatus' where scientists are beginning to re-interrogate if the temporary slowdown in the global average surface temperature warming trend observed between 1998 and 2013 is a genuine slow down or a redistribution of energy in the earth system $[45,84,85]$. Climate variability on the other hand has been defined as variations in the mean state and other statistics (such as standard deviations and the occurrence of extremes) of the climate on all temporal and spatial scales beyond that of individual weather events due to natural internal processes within the climate system (i.e. internal variability), or variations in natural or anthropogenic external forcing (that is external variability) [75].

Findings by the Inter-governmental Panel on Climate Change (IPCC) experts [86-88] and other studies such as Scholes et al. [31], Zachos et al. [2] and Stocker et al. [89] indicate that the earth's climate has experienced complex evolution marked by periodic and anomalous variability both at global and regional scales with diverse impacts on populations throughout-time. Such changing climatic patterns have been linked with various extreme events or phenomena such as droughts and floods $[13,42,54,57$, $90]$. This notion is also buttressed in a review of observed (1900-2000) and possible future (2000-2100) climatic conditions across Africa by Hulme et al. [30] which concluded that the climate of Africa is warmer than it was 100 year ago with some regions experiencing substantial interannual and multi-decadal rainfall variations with dramatic impacts on both the environment and some economies. Impacts of anthropogenic processes on the global carbon cycle and the resultant greenhouse effect have been acknowledged as directly linked to global and regional climatic systems perturbations with the same devastating effects on numerous vulnerable communities around the world, for example $[29,75,88,91,92]$. To mitigate against such impacts, 197 countries signed the 2015 Paris Climate Agreement in which signatories agreed to a goal of holding global temperatures well below $2{ }^{\circ} \mathrm{C}$ above the preindustrial levels and to pursue efforts to limit it to $1.5^{\circ} \mathrm{C}$ [88]. The IPCC further emphasised a dire need for drastic global action [93] to achieve this in light of a narrow window period of up to 2030 to stem catastrophic climate change projected by scientists such as Miller, Croft [94]. However, such global climate change governance efforts have not been without major drawbacks as highlighted 
by the withdrawal of the United States of America (USA) in 2017 from the Paris Accord citing unfairness of the agreement and possible threats to US economic interests [95-97]. Furthermore, it is worth mentioning that the recent SARS-CoV-2 (COVID-19) pandemic has also brought in a new dimension into the existing global climate change research and governance discourse [98-100] though this is not within of the scope of this review.

Climate vulnerability describes the degree to which a system is susceptible to, and unable to cope with, adverse effects of climate change and variability and extremes [75]. It is a function of climate sensitivity and adaptive capacity of communities and natural systems [101]. Climate change increases frequency and intensity of extreme events such as storms, droughts and wildfires which impact on the global food supply, displace communities, and disrupt livelihoods thus increasing the risk of conflict, hunger and poverty [102]. Numerous climate impacts studies covering vulnerabilities and adaptation such as $[15,103-106]$ have been done and the general consensus is that climate change and variability present serious vulnerability challenges (as earlier alluded to) in most regions globally. Within the semi-arid regions in Southern Africa, challenges such as crop failure, land degradation and deforestation are prominent considering their ecosystems and agriculture depend on rainfall for their primary production. In this regard, researchers such as Berrang-Ford et al. [107] have explored human climate adaptation actions while others such as Anwar et al. [108], Lennard et al. [109] and Reddy [13] have in this regard researched on modalities of developing frameworks for characterising and understanding community adaptation capacities to climatic variability and change vis-à-vis the spatio-temporal dynamics of climatic events such as the El Niño-Southern Oscillation (ENSO). Among other conclusions drawn, all these have revealed a need for pragmatic policy development buttressed by sound scientific evidence to guide mitigation and adaptation strategies especially in developing countries such as Zimbabwe [34].

\subsubsection{Climatic change and variability studies in Zimbabwe}

Climate in Zimbabwe is highly variable [110] and thus the country (with its limited coping capacity) is considered highly vulnerable to climate change and variability impacts like most developing countries in Africa, e.g. [86, 91, 111-113]. In light of this, notable response initiatives have been taken by the Government of Zimbabwe (GoZ) in line with SADC climate policy directions. These include the adoption of a National Climate Policy (NCP) augmented by a National Climate Change Response Strategy (NCCRS) and the setting up of a dedicated National Climate Change Management Department under the then Ministry of
Environment, Water and Climate in 2013 (now Ministry of Environment, Tourism and Hospitality Industry). One of the six core objectives of the NCP was to strengthen climate research and modelling and promote relevant homegrown solutions to address the challenges of climate change [71]. Furthermore, the GoZ in partnership with the United Nations Development Programme (UNDP) implemented the National Adaptation Plan (NAP) in the year 2017 which was aimed at analysing the country's shortand long-term climate risks and adaptation options so as to help feed-into the country's NCP and NCCRS up-scaling of climate resilient development initiatives. In 2018, the GoZ set up and launched the Zimbabwe National Geospatial and Space Agency (ZINGSA) under the Ministry of Higher and Tertiary Education, Innovation, Science and Technology Development with one of its mandate being to leverage exploitation of earth observation and geospatial technology in advancing climate science research among other focus areas. These developments have come against the backdrop of the GoZ launching the Zimbabwe Centre for High Performance Computing (ZCHPC) in 2015 aiming at availing supercomputing capabilities to researchers in various field of science such as meteorology (for example in numerical weather prediction/forecasting) and earth-system modelling in the country [114]. Despite these positive developments, not much research has been undertaken to expand knowledge and present updated scientific information on the evolution of past and future climatic conditions in Zimbabwe so as to buttress and enhance the country's resolve/focus in achieving the Sustainable Development Goals (SDGs) such as SDG 1, 2 and 13 (that is No poverty, Zero hunger and Climate action, respectively). A synergy in all these developments, i.e. the ZINGSA, the ZCHPC and other relevant state agencies is critical to realise overall national climate objectives.

Figure 3 shows proportions of the five main identified thematic groups/categories from the climate studies covered under this review while Table 2 gives some examples of the 107 prominent climate studies undertaken in the past 29 years in Zimbabwe under each category. Researchers from Zimbabwean-based research institutions/organisations directly and in collaboration have over this time period contributed approximately $70 \%$ of the studies reviewed herein. The rest are contributions come from researchers affiliated to research institutions outside of Zimbabwe. Climate impact and climate vulnerability, adaptation and mitigation studies are the co-predominant categories of all the studies reviewed (each with 39\%), while climate modelling is the least covered theme ( $9 \%$ ) followed by climate governance studies (8\%). These results reveal a dearth of scientific knowledge primarily within the themes of climate modelling, climate governance and general 
Fig. 3 Graph showing proportions (\%) of the various climate study themes (categories) covered in Zimbabwe in the past 29 years $(n=107)$. Climate impact studies are predominant

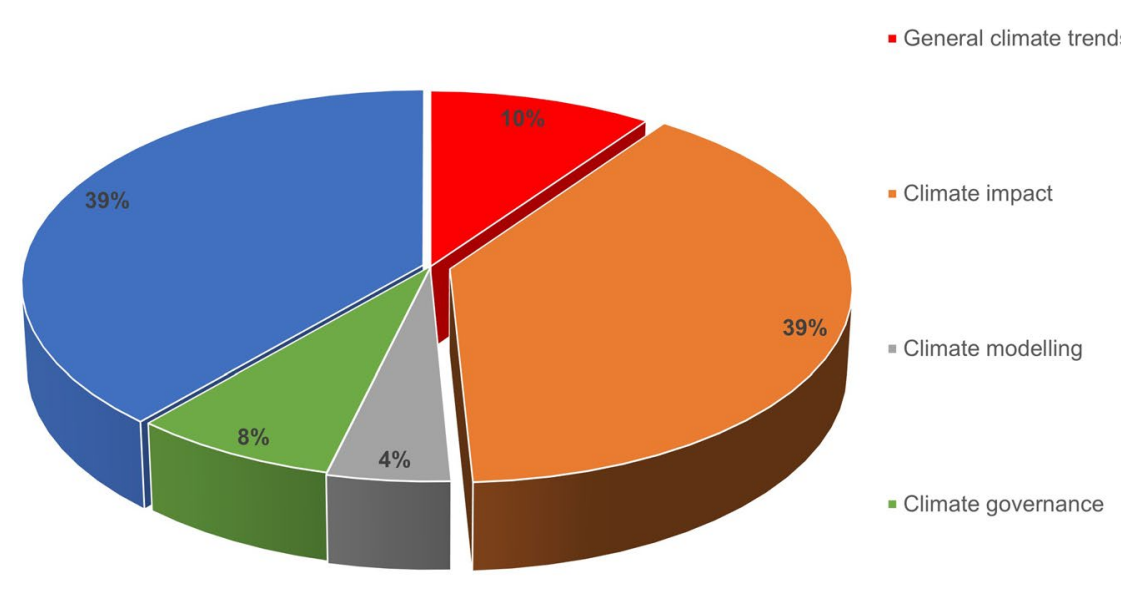

- Climate vulnerability, Adaptation and Mitigation

Table 2 Summary table showing climate study categorisation, examples and statistics for each category

\begin{tabular}{|c|c|c|c|}
\hline Study category & Frequency & $\%$ & Examples of studies \\
\hline General climate trends analysis & 13 & 10 & $\begin{array}{l}(\text { Unganai [115])*, (Unganai [129])*, (Unganai and Mason [120])*, (Williams et al. [339])*, } \\
\text { (Mazvimavi [116]), (Nyoni et al. [293]), (Love et al. [330]), (Mushore et al. [143]), (Sibanda } \\
\text { [341]), (Mamombe et al. [119]) }\end{array}$ \\
\hline Climate Impact & 52 & 39 & $\begin{array}{l}\text { (Booth et al. [333]), (Unganai [117]), (Salewicz [249]), (Kristensen et al. [191]), (Corbett and } \\
\text { Carter [141])*, (Makadho [199]), (Hartman et al. [342])*, (Chemura et al. [331]), (Matarira } \\
\text { et al. [325])*, (Nyanganyura [246]), (Pilossof [237]), (Ebi et al. [236])*, (Brown et al. [130]), } \\
\text { (Mutekwa [327])*, (Williams et al. [339])*, (Gwimbi [242]), (Mugandani et al. [343]), } \\
\text { (Nyabako and Manzungu [231]), (Gwitira et al. [230]), (Chapungu and Nhamo [338]), } \\
\text { (Ncube [235]), (Love et al. [330]), (Phillips et al. [344])*, (Manyeruke et al. [322]), (Davis } \\
\text { and Hirji [253]), (Sango and Nhamo [198])*, (Sande et al. [22]), (Pedersen et al. [21]), (Beck } \\
\text { and Bernauer [250]), (Yamba et al. [223]), (Kutywayo et al. [345]), (Torr and Hargrove } \\
\text { [335]), (Svotwa et al. [324]), (Zinyengere et al. [328]), (Dube et al. [347]), (Bhatasara [287]), } \\
\text { (Zinyemba et al. [369]), (Bossuet and Thierfelder [348]), (Magadza [349]), (Gunda et al. } \\
\text { [336]), (Descheemaeker et al. [350])*, (Chikodzl and Mutowo [337]), (Utete et al. [234]), } \\
\text { (Mamombe [119]), (Lord et al. [192]) }\end{array}$ \\
\hline Climate modelling & 6 & 5 & $\begin{array}{l}(\text { Unganai [115])*, (Ebi et al. [236])*, (Mushore et al. [143]), (Chemura et al. [331])*, (Mashon- } \\
\text { jowa et al. [351]), (Masanganise et al. [323]) }\end{array}$ \\
\hline Climate governance & 10 & 8 & $\begin{array}{l}\text { (Patt [326])*, (Patt and Gwata [197]), (Zinyengere et al. [328])*, (Gutsa [123]), (Mberego and } \\
\text { Sanga-Ngoie [352]), (Ngwenya et al. [122]), (Bhatasara [70]), (Mubaya and Mafongoya } \\
\text { [257]) }\end{array}$ \\
\hline $\begin{array}{l}\text { Climate vulnerability, Adapta- } \\
\text { tion and Mitigation }\end{array}$ & 51 & 39 & $\begin{array}{l}\text { (Matarira et al. [325]), (Matarira and Mwamuka [353]), (Unganai [329])*, (Patt [326])*, (Thi- } \\
\text { erfelder and Wall [121]), (Rurinda et al. [354]), (Chifamba and Mashavira [355])*, (Gwimbi } \\
\text { [242]), (Mudombi-Rusinamhodzi et al. [356]), (Gwenzi et al. [251]), (Nhemachena et al. } \\
\text { [357]), (Soropa et al. [258]), (Dube et al. [346]), (Descheemaeker et al. [350])*, (Chanza } \\
\text { [370]), (Manyani et al. [243]), (Moyo [125]), (Mbereko et al. [358]), (Musarandega et al. } \\
\text { [359]), (Mubaya et al., [257])*, (Chanza et al. [360]), (Mushawemhuka et al. [361]), (Jiri } \\
\text { et al. [362]), (Mugambiwa [260]), (Katsaruware-Chapoto et al. [364]), (Mutandwa et al. } \\
\text { [365]), (Jiri et al. [363]), (Mugambiwa [260]), (Simba et al. [366]), (Nyahunda and Tirivan- } \\
\text { gasi [367]), (Nyahunda et al. [368]) }\end{array}$ \\
\hline
\end{tabular}

NB, Twenty-five (25) of the studies marked with an asterisk $\left(^{*}\right)$ fall within at least two categories considering their scope)

climatic trends, respectively, in Zimbabwe. Results show a publication rate of 3.7 (approximately 4) journal article publications per year over the study period which shows relatively low research output on climate science in Zimbabwe, thus, further demonstrating a knowledge gap in this regard.

One prominent study shown in Table 2 that exclusively explored climate conditions in Zimbabwe is by Unganai 
[115]. This study revealed that over a 93 year period from the $1900 \mathrm{~s}$, daytime temperatures in Zimbabwe rose by about $0.8{ }^{\circ} \mathrm{C}$, translating to a $0.08{ }^{\circ} \mathrm{C}$ rise per decade while precipitation was observed to have declined by up to $10 \%$ on average over the same period, which is about $1 \%$ per decade. These findings, however, were rebutted by Mazvimavi [116] in his study covering 40 rainfall stations across all the rainfall regions of Zimbabwe for periods 1892-1941 and 1942 to 2000. Mazvimavi [116] concluded that the purported climate change effects were not statistically significant within the time series of total seasonal and annual rainfall in Zimbabwe, arguing that the findings of declining rainfall by Unganai [115] were likely due to the presence of multi-decadal variability characterised by combining years with above and below average rainfall. This contrast between two prominent climate researchers presents a need for interrogation of data with new/ updated techniques to bring better clarity with regard to past climatic conditions/trends in Zimbabwe. Since then, no known, published follow-up study has been done to build upon the existing knowledge in this regard.

On rainfall variability, studies have revealed that interannual rainfall variability in the country are largely influenced by external forcing of a near-global or hemispheric origin such the ENSO, the Inter-tropical Convergence Zone (ITCZ) to the North and the westerly cloud-bands to the south rather than regional or local-scale factors [117-119]. On long-term predictability of rainfall trends, Unganai, Mason [120] indicate that approximately $70 \%$ of the total summer rainfall variance in Zimbabwe is potentially predictable at long range due to due to a high climate signal to noise ration especially in the in the eastern, central, and western parts of the country. Over the years, climate-rainfall research has advanced to explore the teleconnectivity between summer rainfall patterns in Zimbabwe and sea-surface temperatures (SST), the Southern Oscillation Index (SOI), the Quasi-biennial Oscillation (QBO), Outgoing Longwave Radiation (OLR) and wind [32]. Nangombe et al. [121], for example, concluded that there are strong correlations between severe droughts and circulation patterns and weather systems in the Indian Ocean and Equatorial Pacific Ocean such as the ENSO SOI, the QBO and the Luni-solar tide at 20, 12.5, 3.2, and 2.7 year cycles. These studies have revealed the possibility of predicting drought occurrences using these established relationships. However, this knowledge is rather outdated and has not been fully utilised by decision makers in Zimbabwe for enhanced drought and other climate impact mitigation fore-planning $[122,123]$. This is evidenced by poor preparation and the resultant recurrent adverse impacts experienced when such events occur.

Within the general climate studies reviewed in this paper, the predominant area of focus has been understanding the rainfall dynamics $[120,121,124,125]$ with less attention on temperature and other climatic parameters such as evaporation, humidity and solar radiation. Limited research on these other climatic parameters could be attributed to limited access to good quality data as revealed by Dlamini et al. [126]. However, some studies that have looked at other climatic parameters such a temperature and evapotranspiration [30, 110, 127, 128] had limited detail that could not give a comprehensive picture of the dynamics of these parameters in space and time in Zimbabwe. For example, though Unganai [129] concluded a net warming of +0.3 to $+0.5^{\circ} \mathrm{C}$ between 1897 and 1993, he could not attribute the observed warming trend to inherent climate variability though similar trends have been later related to climate change by Brown et al. [130] and Watson et al. [131]. Some of these studies have presented the climate dynamics in Zimbabwe in a general sense considering that the studies had a regional scope of coverage (covered Southern Africa) [31, 127, 132, 133]. Furthermore, studies such as Matarira and Jury [134] had limited temporal resolution in their assessments since they used cross-sectional study designs and thus missed exploring the multi-temporal aspects of the climatic conditions in Zimbabwe. In other words, there is a need to build on this existing knowledge through longitudinal studies to capture a more recent picture of multi-temporal climatic trends in Zimbabwe.

While advances in climate research have seen the move towards the use of GIS and RS/Earth observation (EO) technology to (1) augment climate data series, and (2) assist in better and advanced analyses of climate dynamics in space and time globally [135-138] and in Southern African $[139,140]$, progress in this direction has been limited in Zimbabwe. Only $8 \%$ of the reviewed studies in Zimbabwe over the past 29 years have directly and indirectly applied these tools and techniques at varying spatial and temporal scales. Examples include an assessment of interseasonal rainfall variability in Zimbabwe using GIS by Corbett, Carter [141], spatial characterisation of summer rainfall Zimbabwe by Unganai, Mason [118], spatio-temporal analysis of climate-inter-annual malaria incidence [142], and exploring local climate zones-land surface temperature interlinkages using remotely sensed data [143]. This reveals a knowledge gap (of limited use of geospatial tools in climate research) which could be worsened by limited availability of quality in situ climatic data such as rainfall and temperature measurements. Furthermore, where such data is available, often it is incomplete due to poor distribution and investment in necessary infrastructure/ facilities to observe important climatic phenomena. Other data access challenges relate to (1) inaccessibility due to bureaucratic red-tapes and prohibitive costs for long-term climatic datasets charged by government agencies such 
as the Meteorological Department, (2) inconsistent and poor spatial coverage which often renders it of limited use in climate research in the country. This is also confirmed by Gumindoga et al. [144] who noted that historic temperature and rainfall data for Zimbabwe is incomplete and often costly to purchase thus a limiting factor in climate research in general. In light of such limitations, researchers such as Chikodzi [145], Dlamini et al. [126], Kamusoko, Aniya [146] and Mpala et al. [147] have exploited freely available remotely sensed climatic and other datasets to overcome these challenge, notwithstanding the inherent spatial and in some instances temporal resolution limitations of using these datasets at a local scale. The main advantages of using remotely sensed datasets include their availability and access at low to no cost (freely available online) and their ability to give parameter measurements in otherwise inaccessible and ungauged areas at a wider spatial coverage compared to in situ measurement techniques. Disadvantages of remotely sensed data relate to spectral mixing due to low or course spatial resolution, limited temporal resolution which tend to limit time series analysis in some instances and no spatial coverage due to remote sensing satellites' limited repeat cycles. Furthermore, very high purchase costs of higher resolution datasets tend to be prohibitive or limit access and use in developing countries.

\subsection{Climate modelling studies}

\subsubsection{A brief global and regional overview}

Climate modelling science is a highly active field of research with rapid advancements in knowledge marked and driven by rapid developments in the tools and techniques (models) used in this domain. Two main types of models, i.e. Global Climate Models (GCMs) and Regional Climate Models (RCMs), are used in climate modelling studies. GCMs are numerical tools/models representing physical processes in the atmosphere, ocean, cryosphere and land surface used for simulating the response of the global climate system to increasing greenhouse gas concentrations [91]. Examples of GCMs include the Hadley Centre Coupled Model, version $3(\mathrm{HadCM} 3)$, the Commonwealth Scientific and Industrial Research Organisation Mark 3 (CSIRO Mk3) GCM [127, 148], the Geophysical Fluid Dynamics Laboratory Climate Model version 2.5 (GFDL CM2.5) [149] and the Model for Interdisciplinary Research on Climate-Earth Systems Model (MIROC-ESM) [150] and the more recent Hadley Centre Global Environment Model 3-Global Coupled version 3.1 (HadGEM3-GC3.1) [151]. Other variable resolution GCMs such as the ConformalCubic Atmospheric Model (CCAM) of the CSIRO have also been developed for regional climate and weather research
$[152,153]$ and have been applied at different scales globally. Over the years, the GCMs have been used to improve our understanding of how climate systems work, to forecast the drivers of climate change, improve estimates of climate sensitivity and to predict future climatic conditions and impacts, e.g. $[46,89,154,155]$. Advances in this domain have seen the progression from Atmosphere-only GCMS (AGCMs), to Coupled Atmosphere-Ocean models (AOGCM) and fully coupled earth system models (ESM) in an attempt to improve the statistical confidence in the GCM outputs. Thus, the emergence of AOGCMs has allowed for more reliable projections of climate at various spatial and temporal scales [155-157]. This has been realised in light of the well appreciated inherent uncertainties and weaknesses associated with the use of such models. For example, Motesharrei et al. [158] argued that twoway feedbacks are missing from most climate models and other critical socio-economic variables such as inequality, consumption, and population are often inadequately modelled hence increasing uncertainty in outputs. Fowler et al. [159] further emphasise that GCMs have relatively coarse resolutions and hence are unable to resolve significant sub-grid scale features such as land use and land cover (LULC) and topography, thus limiting their accuracy and application at a local scale. To this end, the IPCC and other climate scientists have progressed to implement and develop the Coupled Model Intercomparison Project (CMIP) with the latest being CMIP6 [160]. In CMIP6, various ensembles of GCMs have been run collectively and results compared in an attempt to understand how the global climate will respond to future scenarios of increasing/decreasing anthropogenic radiative forcing relative to present-day climate conditions [157, 161, 162]. For example, Andrews et al. [163] recently ran simulations using the HadGEM3-GC3.1 for CMIP6, testing climatic responses to historical forcings such as solar irradiance, ozone concentrations, greenhouse gases, land-use changes, and aerosols compared results to observational data.

To resolve the shortcomings of GCMs, downscaling techniques [164-166] have been used to develop finer resolution Regional Climatic Models with varying levels of accuracies at sub-grid scale with higher statistical validity and reduced biases compared to GCM simulation outputs. Examples of such RCMs include the Consortium for SmallScale Modelling and Regional Climate Model (COSMOCLM), Regional Climate Model version 4 (RegCM4), and the Providing Regional Climates for Impacts Studies (PRE$\mathrm{CIS}$ ) model. Because of their higher resolution (compared to GCMs), RCM data have been widely used in numerous impact studies as input in hydrological models for example, in an attempt to assess the variability of hydrological responses due to past, present and future climate change scenarios [133, 167-169]. Furthermore, to drive and 
coordinate active research in both dynamic and statistical regional climate downscaling $(R C D)$ techniques of GCMs so as to provide higher-resolution climate information at regional level, the World Climate Research Programme (WCRP) has run the Coordinated Regional Climate Downscaling Experiment (CORDEX) [170]. The CORDEX has, over the years, allowed for an objective assessment and intercomparison of various RCD techniques, i.e. an evaluation of their performance, illustration of benefits and shortcomings of different approaches, thus providing a more solid scientific basis for impact assessments and other uses of downscaled climate simulations. To this end, high resolution regional climate simulations of the CORDEX CORE activity are now available covering all major inhabited areas of the world at a resolution of $25 \mathrm{~km}$ including Africa (Domain: Region 5).

Numerous climate modelling studies have been done both at global and regional scale in an effort to better understand the past, present and future climate dynamics in space and time. While significant progress has been realised in global climate modelling science, e.g. $[5,163$, 171-174], there has been relatively less work published for Africa in the same regard [30] and let alone at local (country) level. Some countries such as South Africa have been leading and have made considerable strides in climate modelling research and actively contributing to the IPCC working groups and the CORDEX-Africa for example. GCMs such as the Canadian Climate Centre Model (CCCM) and GFDL-3 have simulated changes of plus 2 to $4{ }^{\circ} \mathrm{C}$ increases in mean surface air temperature across Southern Africa under doubled atmospheric carbon dioxide scenarios showing over and underestimations when validated with observed data over local areas [128]. Other models that have been applied in Africa include the HadCM3, Parallel Climate Model (PCM) and the Coupled Global Climate Model (CGCM3) [175] showing varying simulation outputs with limited local use considering their inherent uncertainties related to forcings and horizontal biases as discussed by Arora [176].

On the contrary, downscaled RCMs have demonstrated more competence in simulating local climatic conditions compared to GCMs $[165,177-180]$ though the contradictions and parameter over and underestimation of rainfall and temperature scenarios still persists when model outputs are compared [155, 181, 182]. For example, RCMs have shown to successfully simulate future projection of droughts in Southern Africa [179]; predict seasonal and regional climatic scenarios [180]; and project an annualaveraged temperature rise at about 1.5 times the global rate of temperature increase in the African subtropics during the twenty-first century [183]. The general consensus, however, among climate scientists is that projections of future climate change are restricted to assumptions of climate forcing, limited by shortcomings of the climate models used and inherently subject to internal variability when considering specific periods $[165,184-186]$. This justifies the need for sustained research in regional climate downscaling research as supported in CORDEX framework. Resultantly, numerous studies, e.g. [167, 177, 187-190], have been undertaken in Africa and Southern Africa under the CORDEX showing remarkable advancements with more accurate and region-relevant results. Details of the findings of these studies are outside the scope of this review.

\subsubsection{Climate modelling studies in Zimbabwe}

Despite the advances in climate modelling science globally and regionally as earlier alluded to, the scope of climate modelling research in Zimbabwe has been rather limited. Of the 107 prominent climate studies done in Zimbabwe (covered in this review), only $8 \%$ of these directly and indirectly involved climate modelling at some level as earlier shown in Fig. 1. The studies covered climate modelling in relation to aspects such as disease vector distribution, e.g. Kristensen et al. [191], Lord et al. [192] and Gwitira et al. [193], climate impacts on hydrological systems [194-196], agricultural productivity [197] and urban environments and natural ecosystems $[143,195,198]$ and general prediction of future climatic conditions [115]. Unganai [128] used two GCMs (the GFDL and the CCCM) to simulate future climate conditions for Zimbabwe using a doubled carbon dioxide concentration forcing and concluded that the models were inefficient in predicting the magnitude of precipitation change for example. Similarly, Makadho [199] used the same two GCMs to assess potential impacts of climate change on maize production while Matarira and Mwamuka [200] used the Goddard Institute of Space Studies (GISS) model to assess forest vulnerability to climate change. Simulated maize yields decreased considerably under dryland conditions based on the climate change scenarios largely due to shorter growing seasons driven by increased temperatures (ibid). Matarira et al. [201], on the other hand, tested a combined crop model (CERES-Maize) with climate scenarios derived from two GCMs which showed that future low rainfall and high temperature will threaten agricultural production in Zimbabwe. In their stable malaria transmission study, Ebi et al. [202] tested four GCMs, i.e. the CCCM, the United Kingdom Meteorological Office (UKMO) model, and the GISS model to simulate and relate future climatic scenarios to malaria transmission. They concluded that changes in temperature and precipitation due to climate change could alter the spatial distribution of malaria in Zimbabwe, with previously unsuitable areas of dense human population becoming suitable for transmission. 
From all these reviewed modelling studies, most used GCM simulations directly, which could have had negative implications on the accuracy of their findings due to the known inherent limitations of GCMs application at a local level. A few exceptions such as Pedersen et al. [21] and Moyo, Nangombe [133] attempted to use RCMs and applied downscaling techniques to generate more accurate climate simulations from GCMs for their studies. For example, Makuvaro [203] used Statistical and Regional dynamic Downscaling of Extremes for European regions (STARDEX) to come up with downscaled local scenarios for his study. Overall, it is emerging that most of these studies have used GCMs and RCMs (downscaled or directly) with limited regard of inherent limitations of these different models implying possible inaccuracies in some of the findings and conclusions of these studies. This is in light of the fact that most models are developed to be more region specific and transferring them to or applying them in other regions of the world will give inaccurate results by the inherent design of the models. Furthermore, considering the advances in revision and/or improvements on old climate models and the development of new, better and region specific models, e.g. under the CORDEX programme $[167,168]$, it is apparent that there is a need to revisit and advance climate modelling science in Zimbabwe. This means testing new, and advanced region specific downscaled RCMs or GCMs so as to help fill the earlier discussed climate science knowledge gaps in the country. We also found that no known study has been done to comparatively assess the competence of the more recent RCMs and GCMs in simulating local climate over Zimbabwe. Furthermore, there has been no development of contextual optimization of RCMs to improve their skill in reproducing local climatic characteristics building on the research work covering Southern Africa by scientists such as Engelbrecht et al. [204], Dosio [205] and Abiodun et al. [206]. Such research advances and the ensuing results could help inform more contextual national climate adaptation and mitigation policy appraisal and response strategy development by the GoZ as earlier discussed.

\subsection{Climate change/variability impact studies}

\subsubsection{A general global overview}

A number of climate scholars have explored the impacts of climate change and/or variability on various natural and human systems $[54,75,91,184,207-210]$ and the results indicate heightened community vulnerabilities $[12$, $104,106,211,212$ ] at a global, regional and local scale. Amongst other noted impacts, most of the studies have shown that climate change has an overall negative impact on hydrological systems in the world [213-215]. Arnell [6] for example, noted reduced runoff in the Mediterranean, Central and Southern America, and Southern Africa and increased evaporation in some areas $[140,216]$. In Southern Africa, climate change has also been linked to the $\mathrm{EI}$ Niño-Southern Oscillation (ENSO) induced droughts, e.g. $[132,168,178,217-219]$ with devastating effects on communities and the environment in general. Several studies have quantified the extent of impacts and their dynamics (in space and time) on water resources [5-9]; food security [12-14, 220]; ecosystems, e.g. [17, 209, 221, 222]; energy, e.g. [146, 223-226]; and human health [21, 22, 227]. All these studies have revealed that climate change is a very significant factor to consider in holistic planning for community resilience and adaption for sustainable development, and more importantly in African developing countries such as Zimbabwe. Considering the intricate coupling of the human and natural systems, most of these studies have used diverse advanced methods in an attempt to understand the climate change dynamics vis-à-vis all the earlier mentioned factors. Of note has been the widespread use of climate model simulations (from both GCMs and RCMs) in climate impact models to explore how natural and human systems may be affected by climate change $[6,155]$. That is, the climate simulations have been used in integrated climate change impacts assessments notwithstanding the limitations of under and overestimating some climate extremes impacts revealed by Schewe et al. [228].

While these impacts are well acknowledged to be more devastating in vulnerable communities in developing countries due to their weak institutional arrangements and policies for resilience and adaptation [103], climate science research still lags behind in most of these countries $[16,76$, 229]. This has heightened future climate vulnerability due to limited scientific knowledge to guide pragmatic policy development and strategies for adaptation and resilience.

\subsubsection{Climatic change impact studies in Zimbabwe}

In this review, 52 of the 107 (39\%) climate studies done in Zimbabwe over the past 29 years were found to be climate impact studies as earlier alluded to. Table 3 and Fig. 4 show thematic summaries of our findings in this regard. The emerging themes/categories covered by these studies ranged from climate agricultural impacts [199, 230-232]; socio-economic impacts [130, 233, 234]; ecological impacts, hydrological impacts, e.g. $[117,194$, 235]; energy impacts [224]; and health impacts, e.g. [236, 237]. Agricultural impacts, ecological impacts and health impacts studies were found to be the three top categories of impact studies while energy impacts studies were the least covered category over the past 29 years in Zimbabwe as shown in Fig. 4. The scope of coverage 
Table 3 Summary table showing climate impact studies categories and study examples done in Zimbabwe from 1990 to 2019 ( $n=52$ )

\begin{tabular}{|c|c|c|}
\hline Study theme & Frequency & Examples of studies \\
\hline Socio-economic impacts & 6 & $\begin{array}{l}\text { (Matarira and Mwamuka [201]), (Dube et al. [255]), (Brown et al. [130]), (Manyeruke et al. [322]), (Utete } \\
\text { et al. [234]) }\end{array}$ \\
\hline Agricultural impacts & 18 & $\begin{array}{l}\text { (Corbett and Carter [141]), (Makadho [199]), (Gwimbi [242]), (Matarira et al. [325]), (Masanganise } \\
\text { et al. [323]), (Svotwa et al. [324]), (Patt and Gwata [197]), (Nyabako and Manzungu [231]), (Mutekwa } \\
\text { [327]), (Zinyengere et al. [328]), (Unganai [329]) }\end{array}$ \\
\hline Hydrological impacts & 7 & $\begin{array}{l}\text { (Unganai [117]), (Salewicz [249])*, (Davis and Hirji [253]), (Love et al. [196]), (Chemura et al. [331]), } \\
\text { (Mamombe [119]) }\end{array}$ \\
\hline Ecological impacts & 17 & $\begin{array}{l}\text { (Nyanganyura [246]), (Gwitira et al. [230]), (Marshall 332), (Booth et al. [333]), (Sango et al. [198]), } \\
\text { (Pilossof [237])*, (Gandiwa and Zisadza [334]), (Sango and Nhamo [198]), (Magadza [349]), } \\
\text { (Pedersen et al. [21])*, (Chikodzl and Mutowo [337]), (Chapungu and Nhamo [338]), (Gwitira et al. } \\
[193])^{*},(\text { Matawa et al. 2013) }\end{array}$ \\
\hline Energy impacts & 3 & $($ Salewicz [249])*, (Spalding-Fecher et al. [224]), (Yamba et al. [223]) \\
\hline Health impacts & 9 & $\begin{array}{l}\text { (Williams et al. [339]), (Ebi et al. [236]), (Gwitira et al. [193])*, (Pilossof [237])*, (Pedersen et al. [21])*, } \\
(\text { Torr and Hargrove [335]), (Gunda et al. [336]), (Kristensen et al. [191]) }\end{array}$ \\
\hline
\end{tabular}

NB, Eight (8) of the studies marked with an asterisk $\left(^{*}\right)$ fall within at least two categories considering their scope

Fig.4 Chart showing proportions (\%) of the various climate impact study themes covered in climate studies in Zimbabwe in the past 29 years. Ecological and agricultural impacts are the predominant themes covered by the impact studies $(n=52)$

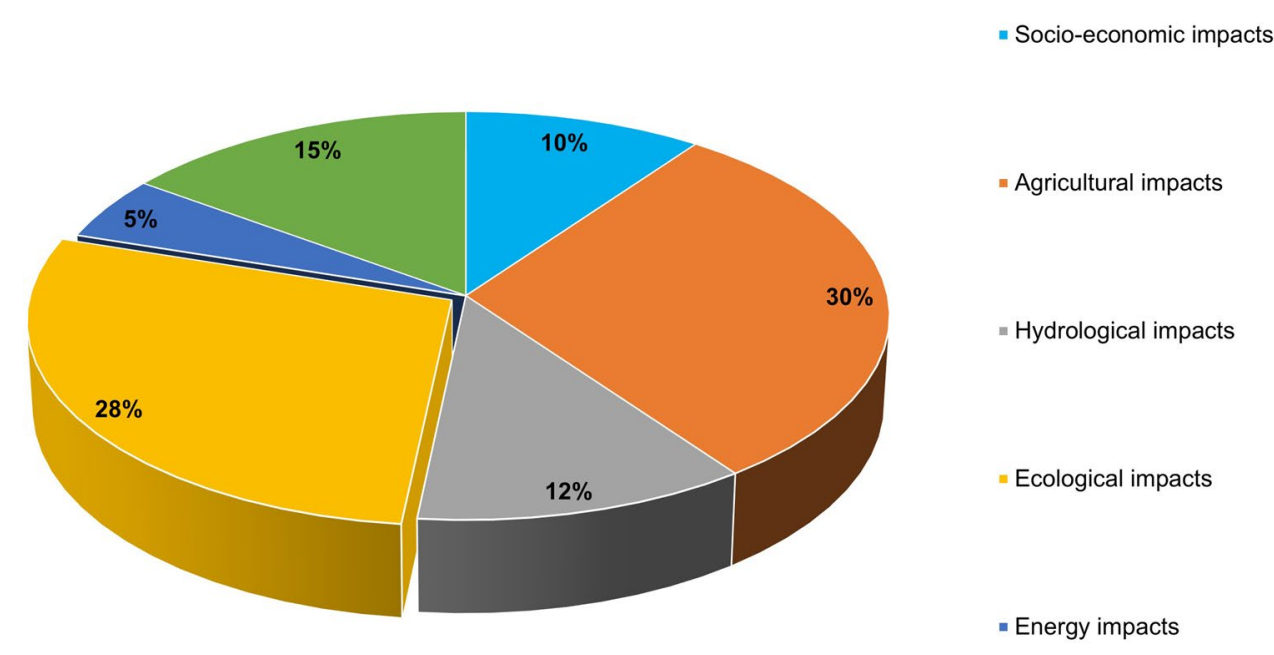

- Health impacts of these studies ranged from national through district, ward to catchment level. This basically revealed limited and, in some instances, outdated scientific knowledge in the least covered categories (i.e. socio-economic, energy and hydrological impacts of climate change). With limited research output informing climate impact on energy, it may imply that planning for energy security in the face of climate risks could be a major contributing factor to the persistent energy problems that the country has been grappling with. The energy crisis has compounded over the years climaxing with the recent (2019) near total shutdown of the country's main hydroelectricity power source, i.e. the Kariba South Power station due to poor rains and the resultant low inflows into the Kariba reservoir [238].
Some of the emerging general conclusions from the reviewed impact studies are presented hereon. Climateagricultural impact studies generally revealed that smallholder agricultural production is significantly constrained by high temperature and low rainfall in Zimbabwe [233] and that climate change has compounded Zimbabwean peasant farmers' climate vulnerability, e.g. to drought hence food insecurity and poverty [239]. This has necessitated pragmatic adaptive management of agro-biodiversity to ensure equitable sharing of resources in the face of climate change and uncertainties as suggested by Masocha et al. [240]. Given that smallholder and subsistence farmers are highly vulnerable to climate change [241], there is need for deliberate investment in climate adaptation strategies and clear policies on irrigation and early 
warning systems to bolster the farmers' climate resilience $[141,230]$ in line with the Southern African Development Community (SADC) Climate Change Adaptation Strategy [103]. Crop production has also been related to climatic conditions in some of these studies. For example, cotton production levels were noted to have declined as precipitation decreased and temperatures increased in Gokwe district of Zimbabwe [242], while maize productivity has been projected to decrease in response to various global climate change scenarios $[231,243]$. The ENSO has been successfully linked to rainfall, drought and maize yield, e.g. [231, 242, 244-247] and livestock productivity [248]. Within agro-ecology impacts, Mugandani et al. [135] and Chingombe et al. [245] agree that the main food production regions of Zimbabwe (regions 1 and 2) are likely to decrease in size due to climate change and variability pointing to possible reduction in food production and food security hence the need to have commensurate mitigation measures to avert potential negative impacts.

As earlier presented, there are other emerging themes related to ecosystem impacts [21]. Matarira and Mwamuka [200] in their modelling study projected a 17 to $18 \%$ land area shift from subtropical thorn woodland and subtropical dry forest to tropical very dry forest under a modelled climate scenario of reduced precipitation and an increase in ambient temperatures. Climate change/variability has been shown to be a current and future threat to energy security in
Zimbabwe, i.e. hydroelectric power potential will be reduced in all existing and proposed hydroelectric power schemes due to climate change and increasing water demand, e.g. $[131,223,249,250]$. The energy-climate link is already evident as earlier discussed in the recent Kariba power station situation. With regard to public health, literature reviewed in this study indicate negative impacts/trends, e.g. results from a climate suitability for stable malaria transmission in Zimbabwe under different climate change scenarios by Ebi et al. [202] suggest that changes in temperature and precipitation could alter the spatial distribution of malaria in Zimbabwe, with previously malaria unsuitable areas of dense human population such as Bulawayo becoming suitable for transmission. Gwitira et al. [193] and Ebi et al. [236] have all concluded that climatic factors such as temperature and annual precipitation are critical factors intricately linked to current and possibly future changes in distribution of malaria in Zimbabwe. Other studies are indicating changes in abundance and distribution of tsetse flies, suggesting possible redistribution of African trypanosomiasis (sleeping sickness) incidence in Zimbabwe in the future due to climate change [237]. Table 4 presents some of the projected climate impacts by sector for year 2080. Of note is that projections indicate worsening of negative impacts in almost all the sectors under consideration. For example, runoff is projected to decrease significantly within major catchments such as the Save and the Mzingwane with wide-ranging consequences

Table 4 Projected climate change impacts by sector in Zimbabwe. (Adopted from [251])

\begin{tabular}{|c|c|c|}
\hline & Sector & Projected climate change impacts \\
\hline 1 & General & $\begin{array}{l}\text { Predicted warming of around 2degrees Celsius by } 2080 \\
\text { Present southwest-northeast-east rainfall gradient will become steeper }\end{array}$ \\
\hline 2 & Agriculture & $\begin{array}{l}\text { General vulnerability of communal agriculture to climate change and variability } \\
\text { Generally, maize suitable areas will decrease by } 2080 \text {, while cotton and sorghum suitable areas will increase } \\
\text { by } 2080 \\
\text { In the south western parts of the country, sorghum and maize will become increasingly vulnerable to cli- } \\
\text { mate change while cotton will become less vulnerable } \\
\text { In the north central and eastern parts of the country, maize, sorghum and cotton will become less vulner- } \\
\text { able }\end{array}$ \\
\hline 3 & Water & $\begin{array}{l}\text { Overall, surface water resources are projected to be reduced significantly by } 2080 \text { irrespective of the sce- } \\
\text { nario used } \\
\text { North eastern and the eastern parts of Zimbabwe are predicted to experience a surplus in surface water } \\
\text { while the western and southern parts of Zimbabwe are projected to experience a drying up } \\
\text { Runoff will decrease significantly in the Mzingwane, Shashe, Nata, and Save catchments }\end{array}$ \\
\hline 4 & Health & $\begin{array}{l}\text { The area under high to extremely high malaria hazard will tend to increase by } 2080 \\
\text { High malaria hazard will be concentrated in the low lying parts of the country including the Zambezi valley, } \\
\text { and the South-east Lowveld } \\
\text { Expected minimum pressure on plant diversity for best and worst case scenarios is } 42 \%\end{array}$ \\
\hline 5 & Forestry and biodiversity & $\begin{array}{l}\text { Net Primary Production (NPP) will decrease from the current average maximum of over } 8 \text { tonnes per hectare } \\
\text { per year to just over } 5 \text { tonnes per hectare per year by } 2080 \text { translating to decreased rangeland carrying } \\
\text { capacity for both livestock and wildlife }\end{array}$ \\
\hline 6 & Human settlement & Any reduction in available water will lead to increased water scarcity thus impacting on livelihoods \\
\hline 7 & Tourism & $\begin{array}{l}\text { With decreasing rainfall and rising temperatures, significant declines in biodiversity are expected to occur in } \\
\text { most parts of the country especially the western regions where most of the park estates are located } \\
\text { Lower resilience of ecosystems to other global environmental changes }\end{array}$ \\
\hline
\end{tabular}


for resident communities and in the face of high vulnerability and low resilience.

Some researchers in Zimbabwe such as Cobo et al. [252] and Davis, Hirji [253] corroborate the acknowledged conclusion by the IPCC [172] and Watson et al. [131] that observational records and climate projections provide abundant evidence that freshwater resources are vulnerable and will be strongly impacted by climate change, with wide-ranging consequences for human societies and ecosystems globally. Studies on climate impacts on water resources all indicate negative trends, i.e. reduction in water reservoir water levels, increased evaporation and surface and groundwater storage and hydro-electricity potential $[134,232,235,254]$ which are directly related to climate impacts on rainfall and temperature. Very few studies have focused on modelling the hydrological impacts of climate change and variability in Zimbabwe indicating a gap in knowledge in this regard. These are covered more extensively under hydrological modelling studies section of this review. Of note also is that $11 \%$ of all the climate impact studies reviewed here, directly and indirectly employed climate modelling and climate impacts modelling techniques in their methodologies notwithstanding the rapid advancements within this domain. This limited utilisation of these advanced climate modelling tools and techniques thus presents a need to advance research in this direction so as to expand knowledge and close such apparent gaps in climate impact studies in Zimbabwe for informed policy formulation and interventions. The same can be said about studies exploring climate impact on the tourism sector in Zimbabwe especially considering the revealed interlinkages between the aviation industry and climate change and the potential negative impacts such as threats to wild life which may undermine future tourism operations and activities $[255,256]$.

Relative to these developments in methodologies in climate impact studies, there has been an increase in the integration of indigenous knowledge systems in climate research in Zimbabwe over the past decade. These studies have chattered a new frontier in climate research aimed at understanding aspects such as seasonal climate forecasts [257-259] and local climate adaptation practices and strategies, e.g. [243, 260-262]. Developments in this regard indicate a drive to leverage and streamline the existing local indigenous knowledge in the development of pragmatic, low-cost local climate interventions and mitigation strategies.

\section{Hydrological modelling}

\subsection{Hydrological modelling studies: a general overview}

Hydrological models are representative simplifications of complicated hydrological processes using mathematical means to demonstrate the principal elements of the processes, their combination and function as a comprehensive hydrologic system [263]. These hydrological models have been classified in various ways but Refsgaard and Knudsen [182] grouped them into three broad categories namely, (1) empirical black box models, (2) lumped conceptual models, and (3) distributed physically based system. Examples of these include the TANK model [264], Hydrologic Engineering Center's Hydraulic Modeling System (HEC-HMS) [265, 266], TOPMODEL, Système Hydrologique Européen (SHE), Soil and Water Assessment Tool (SWAT) $[267,268]$ and complex conceptual models such as MODified HYDROLOG (MODHYDROLOG) [269]. A review of the pros and cons of these models by Sivapalan et al. [270] and Jaiswal et al. [271] revealed that distributed physically based models have the advantage of accounting for spatial heterogeneities and provide detailed description of the hydrological processes in a catchment with limited demands of input data hence their widespread use in numerous hydrological studies [266, 272-276]. The same notion was confirmed by the World Meteorological Organization [181] in their inter-comparison of conceptual hydrological models for operational hydrological forecasting. Furthermore, considering that these models use parameters which are directly related to the physical characteristics of the river basins (e.g. topography, soil, LULC and geology) and account for spatial variability of meteorological conditions [182]. They have been very useful in studies advancing the understanding of changes in hydrological processes such as surface run-off $[264,269,277,278]$ and groundwater storage $[7,279]$ over space and time and simulating future hydrologic conditions.

\subsection{GIS and remote sensing in hydrological modelling}

As alluded to earlier on, over the years, GIS and RS techniques have become indispensable in most state-ofthe-art hydrological models premising on the extensive spatio-temporal data capture and analysis capabilities of these technologies. Three main applications of RS in hydrological modelling presented in numerous studies can be summarised as, (1) model parameter estimation 
with the aid of multi/hyper-spectral satellite data; (2) computation of historic monthly runoff using satellite data as input; and (3) real-time flood forecasting using radar rainfall measurements as input $[280,281]$. In this regard, many researchers have used GIS and RS in hydrological modelling studies aimed at optimisation of catchment management in the Mediterranean regions [282], water resources management in India [283, 284], forest hydrology [285-287], assessing water quality visà-vis human activities in Korea [288], monitoring small dams in semi-arid regions $[289,290]$ and general parameterisation of hydrological models [273, 291-293]. GIS and RS have been noted to have a major advantage of accurately sizing and characterising catchments in rainfall-runoff modelling over and above the fact that analysis can be performed much faster, especially when there are complex mixtures of land use classes and different soil types [294]. In Africa, numerous studies [40, 286, 295-299] have also exploited the same tools and techniques to advance knowledge in this domain. This has been enhanced by improved and free access to valuable satellite earth observation data from various systems such as Meteorological satellites [300], and Tropical Rainfall Measuring Mission (TRMM) [139, 301]. All these studies indicate that globally, GIS and RS have become an almost indispensable part of hydrological modelling studies over the past decades.

To this end, in the face of considerable uncertainty in determining water availability/security relative to climate and land use-land cover changes which impact of hydrologic conditions, it is critical for water resources managers and decision makers to have a better and simplified understanding of past, present and ideally future hydrological processes dynamics/scenarios through sound water resources studies (which leverage GIS and Remote sensing technology) [302].

\subsection{Hydrological modelling studies in Zimbabwe}

Of the 107 studies reviewed in this study, 7\% directly and indirectly involved hydrological modelling, indicating very limited hydrological modelling research in Zimbabwe over the period under review. Hydrological modelling studies in Zimbabwe date back to 1986 when Knudsen et al. [303] tested the capability of the WATBAL model in simulating ungauged catchments using medium size dams in Zimbabwe. Another early study is by Vörösmarty, Moore [304] who used a simple catchment-scale model to simulate seasonal variation in discharge in the Zambezi river and how it might respond to climate and land use change. Though developments have been slow in the past 29 years, advances made thus far have seen shifts from use of simple statistical models to empirical-black box models, lumped conceptual models and more recently to coupled distributed physically based hydrological models such as SWAT and HecHMS. For example, Love et al. [305] used an empirical model (the Hydrologiska Byråns Vattenbalansavdelning (HBV) model) to simulate hydrological processes in the Northern Limpopo basin (Mzingwane catchment), while the HEC-HMS model has been successfully used in simulating run-off in the gauged and ungauged Upper Manyame sub-catchments of Zimbabwe $[306,307]$. The same model has been applied by Gumindoga et al. [144] in modelling the water balance of the Lower Middle Zambezi Basin, successfully estimating the total inflows into the Cahora Bassa Dam and recommending ways of managing artificial floods in this basin. Mazvimavi [308] successfully demonstrated the application of two lumped conceptual models, i.e. the Thomas abcd model [309] and the Pitman model [310] to estimate catchment descriptors such as flow characteristics in 52 ungauged sub-catchments in all the seven main catchments of Zimbabwe. Other models that have been used in Zimbabwe include the Surface Energy Balance System (SEBS) Water Balance Model to determine actual evapotranspiration in the Upper Manyame catchment [311] and the TOPMODEL to simulate streamflow of Upper Save River catchment [312]. The flownet computational and modelling method [313] has been applied as well in groundwater recharge modelling within the Gwayi catchment. From these studies, it is apparent that the shift has been from lumped, empirical/mathematical-based models towards distributed physically based models in hydrological studies in Zimbabwe over the past 29 years.

A review of the scope of coverage of these studies revealed that all seven water catchments in Zimbabwe (i.e. the Gwayi, Manyame, Mzingwane, Runde, Sanyati, Mazowe and the Save catchment shown in Fig. 2) have been studied at varying degrees using various hydrological modelling techniques and tools. However, most of these studies have been done in the Zambezi basin catchments, i.e. the Mazowe and the Manyame catchments [144, 306, 314]. Catchments to the North-eastern and South-western part of the country, i.e. the Gwayi and the Save catchments have received very limited attention in terms hydrological modelling research over the years, while the Mzingwane catchment has had four prominent studies $[196,305,315$, 316] that directly applied modelling techniques over the past two decades showing a knowledge gap in this regard. Furthermore, in as far as the integration of land use and land cover change, and climate modelling in hydrological modelling studies is concerned, it was noted that very few studies, i.e. approximately $15 \%$ of hydrological studies done to date have attempted to advance knowledge in this direction. In other words, utilisation of advanced, coupled distributed physically based hydrological modelling 
techniques to expand the scope of understanding of the climate-land use-hydrology nexus in Zimbabwe has been very limited thus showing a huge knowledge gap in this regard. However, other non-modelling hydrological studies have been done in almost all catchments in the country covering various themes such as reservoir capacity and sedimentation rate estimation [279, 317], groundwater yield estimation [254], water quality assessment [318], in-field and rainwater harvesting [319, 320] and general catchment characterisation - water balance relationships $[305,315]$.

Though there has been tremendous advances in integration/streamlining of GIS and RS in hydrological modelling research globally over the past decades as earlier discussed [191, 298, 302], in Zimbabwe however, very few studies, e.g. [144, 145, 240, 254, 279, 306, 321] have applied these tools and techniques showing a need to expand knowledge in this area leveraging these techniques. This could be attributed to limited expertise and GIS and RS infrastructure/equipment to fully streamline the use of the techniques in hydrological modelling studies. This could also be exacerbated by the earlier highlighted challenges of limited accessibility and availability of good quality in situ climatic /meteorological data such as rainfall and temperature measurements in the country.

\section{Conclusion}

\subsection{Climate change/variability studies}

Despite the developments in climate and hydrological research, and the already confirmed climate impacts on human livelihoods, economies and general well-being and water resources in Zimbabwe, the scope of understanding of the climate-land use-hydrology interlink is still limited/poor. It has gaps as revealed in our study. Similarly, climatic conditions studies in Zimbabwe covered in this review present varying and in some instances contradictory conclusions though most agree that the climate has been changing or varying considerably in space and time with a temperature rise of less about $0.1^{\circ} \mathrm{C}$ and an approximately $10 \%$ decrease per decade for rainfall over the 1900 to 1993 period. Follow up studies in this regard basically indicate the same temperature and rainfall trends though magnitudes of change have been varying and, in some instances, contradictory owing to the different methodologies used in these studies. It was noted that the use of different methodologies in the analysis of data in these studies further compounds the problem of comparability of findings. For example, some studies used simple parametric inferential statistics to test for significance of climatic trends while others used non-parametric techniques on the same. This basically shows the need for care in interpreting and/or comparing study findings in this regard. Furthermore, new and more robust climate trend analysis techniques have been developed over the years which can be utilised to re-interrogate the available climate datasets with more scientific rigor to close knowledge gaps related to biases and inaccuracies of some of the past studies covered in this review.

We can conclude that climate change and variability impact studies and climate vulnerability, adaptation and mitigation studies are the two-predominant categories of climate studies in Zimbabwe while climate modelling and governance study themes were the least covered. For climate impact studies, there has been greater bias towards agricultural and ecological impact themes with very limited coverage of energy and socio-economic climate impacts. Other themes that emerged included climate impacts on health and hydrological systems. Findings in this regard converged on this general conclusion asserted by the IPCC that Zimbabwe is a highly climate vulnerable country with limited resilience and poor adaptation policies and strategies in place to avert the inherent impacts of climate change and variability, notwithstanding the availability of relevant legislation and institutional framework, policy and strategies (e.g. the NCP, NAP, ZINGSA, ZCHPC and the NCCRS). Furthermore, considering that the global and regional climate forecasts indicate worsening of conditions, it is thus very important that climate science in Zimbabwe is updated to generate new and contextual knowledge leveraging on cutting edge recently developed tools and techniques rather than rely on outdated conclusions from past studies to inform climate policy formulation and strategy development for the country.

Furthermore, in this review, it emerged that climate modelling research is still a largely grey area in Zimbabwe. Most past studies have used GCMs and only a few have used RCMs with limited to no bias corrections and due consideration of the region-specific nature of most of these models. The implication of this are potential biases and errors and thus limited local applicability of some of their findings considering also recent developments and cautions in application of these tools at a local scale. This, thus, necessitates further expansion of knowledge on the same by leveraging on the potential presented by new and advanced Southern Africa regions-specific GCMs and RCMs such as the CCAM which have the ability to generate accurate climate perturbations at regional and local scale through advanced downscaling and bias correction techniques. New studies could expand knowledge by modelling impact scenarios within agriculture, biodiversity and hydrology such as surface run-off which influences overall water availability and thus security in Zimbabwe. Advancing knowledge in this regard will be vital especially 
for identifying, for example, the hydrologic consequences of changes in important climatic variables such as temperature, precipitation, and other landscape variables such as land use-land cover. This could contribute to holistic policy development and effective planning of current and future water management and security interventions. Furthermore, highly prohibitive costs of in situ current and historic climate and hydrological data imposed by governmental agencies such as the Zimbabwe National Water Authority (ZINWA) and the Meteorological Services Department are noted to be one of the potential serious bottlenecks impeding climate science research in the country. It is therefore important for the Government of Zimbabwe to address this by coming up with more pragmatic data-access policies that will make climate datasets more easily available and accessible to the Zimbabwean scientific community so as to encourage more research. This will allow for unhindered fast progress or advancement of climate science research in Zimbabwe, exploiting also the available national supercomputing capabilities at the ZCHPC.

\subsection{Hydrological modelling studies}

Hydrological modelling is a relatively grey area of research in Zimbabwe with very few studies reviewed herein covering this research domain. Of the seven water catchments in Zimbabwe, the Manyame and the Mazowe catchments have received most attention as frontiers of hydrological modelling research in Zimbabwe whilst the Gwayi, the Runde, the Save and the Sanyati catchments have had least coverage. While some hydrological modelling research has been done on the Mzingwane catchment, the scientific knowledge is outdated, i.e. has been outpaced by advances in techniques and tools developed and used in this domain over the past two decades globally. With such knowledge gaps, vis-à-vis the already acknowledged highly vulnerable climate of Zimbabwe and the predicted worsening future climatic conditions in the country, it thus becomes very critical that deliberate efforts cascading from policy level, prioritise climate-hydrology modelling research in Zimbabwe. This is because all these aspects speak to present and future sustainable development in terms of water security and livelihoods.

Regarding the types of models, there is generally a need to test or apply new/advanced coupled hydrological models to better understand interlinkages between climate-hydrology and land use in Zimbabwe to update existing knowledge to be abreast with global and regional developments within this domain. In order to achieve this, approaches encompassing coupling of distributed hydrological models and properly downscaled GCM/ RCM simulations as advocated for by various researchers should be considered. Such approaches could enhance understanding of local feedback mechanisms and interrelations between key natural-human systems influencing community livelihoods which is a specialised area of research within this domain. Furthermore, we note a relatively new and important frontier of climate-hydrology research, i.e. integration of indigenous knowledge systems (IKS) in the context of climate adaptation and mitigation in Zimbabwe which has to be encouraged and streamlined within this domain.

Overall, we conclude that climate science and hydrological modelling research in Zimbabwe is lagging behind vis-à-vis global and regional developments within these domains and thus the need to adopt a more systematic and holistic approach exploiting among other tools and techniques, coupled systems-based approaches (integrating climate-land use-hydrological modelling and GIS/ RS) for better understanding of past, present and future climatic conditions and their hydrological impacts. This should be done without negating the need of developing new and/or fine-tuning the existing climate related and other relevant policy, legislative and institutional frameworks in Zimbabwe.

Acknowledgements Gratitude goes to the National University of Science and Technology (Bulawayo, Zimbabwe) for all the support rendered to the corresponding author to undertake this study at the University of the Witwatersrand (Johannesburg, South Africa).

Authors' contributions Both authors contributed in the ideation of the article. Literature search and data analysis were performed by corresponding author. The first draft manuscript was written by corresponding author and critically revised by co-author. The final draft manuscript was read and approved by both authors.

\section{Declarations}

Conflict of interest Both authors declare that they have no conflict of interest.

Open Access This article is licensed under a Creative Commons Attribution 4.0 International License, which permits use, sharing, adaptation, distribution and reproduction in any medium or format, as long as you give appropriate credit to the original author(s) and the source, provide a link to the Creative Commons licence, and indicate if changes were made. The images or other third party material in this article are included in the article's Creative Commons licence, unless indicated otherwise in a credit line to the material. If material is not included in the article's Creative Commons licence and your intended use is not permitted by statutory regulation or exceeds the permitted use, you will need to obtain permission directly from the copyright holder. To view a copy of this licence, visit http://creativecommons. org/licenses/by/4.0/. 


\section{References}

1. Bronnimann S (2015) Climatic changes since 1700. Advances in global change research. Springer, Cham

2. Zachos J, Pagani M, Sloan L, Thomas E, Billups K (2001) Trends, rhythms, and aberrations in global climate $65 \mathrm{Ma}$ to present. Science 292(5517):686

3. Easterbrook DJ (2016) Evidence-based climate science: data opposing $\mathrm{CO}_{2}$ emissions as the primary source of global warming. Elsevier, Amsterdam

4. Pecl GT, Araújo MB, Bell JD, Blanchard J, Bonebrake TC, Chen IC, Clark TD, Colwell RK, Danielsen F, Evengård B, Falconi L, Ferrier S, Frusher S, Garcia RA, Griffis RB, Hobday AJ, JanionScheepers $C$, Jarzyna MA, Jennings $S$, Lenoir J, Linnetved HI, Martin VY, McCormack PC, McDonald J, Mitchell NJ, Mustonen T, Pandolfi JM, Pettorelli N, Popova E, Robinson SA, Scheffers BR, Shaw JD, Sorte CJB, Strugnell JM, Sunday $J M$, Tuanmu M-N, Vergés A, Villanueva C, Wernberg T, Wapstra E, Williams SE (2017) Biodiversity redistribution under climate change: impacts on ecosystems and human well-being. Science 355(6332):9214. https://doi.org/10.1126/science.aai92 14

5. Arnell NW (1999) Climate change and global water resources. global environmental change 9. Supplement 1:S31-S49. https://doi.org/10.1016/S0959-3780(99)00017-5

6. Arnell NW (2004) Climate change and global water resources: SRES emissions and socio-economic scenarios. Glob Environ Change 14(1):31-52. https://doi.org/10.1016/j.gloenvcha.2003. 10.006

7. Gurdak JJ, Hanson RT, Green RT (2009) Effects of climate variability and change on groundwater resources of the United States. US Geol Surv Fact Sheet 2009-3074

8. Hanson RT, Dettinger MD (2005) Ground-water/surface-water responses to global climate simulations, Santa Clara-Calleguas Basin, Ventura County, California, 1950-93. J Am Wat Res Assoc. https://doi.org/10.1111/j.1752-1688.2005.tb03752.x

9. Maina J, de Moel H, Vermaat JE, Henrich Bruggemann J, Guillaume MMM, Grove CA, Madin JS, Mertz-Kraus R, Zinke J (2012) Linking coral river runoff proxies with climate variability, hydrology and land-use in Madagascar catchments. Mar Pollut Bull 64:2047-2059

10. Moumen Z, El Idrissi NEA, Tvaronavičienè M, Lahrach A (2019) Water security and sustainable development. Insights Reg Dev 1(4):301-317

11. Bodansky DM, Brunnée J, Hey E (2020) Water security and climate change. In: Just add water: solving the world's problems using its most precious resource. Oxford University Press, Oxford, p 259

12. Pielke RA (2013) Climate vulnerability: understanding and addressing threats to essential resources. Academic Press, Amsterdam

13. Reddy PP (2014) Climate change adaptation. In: Climate resilient agriculture for ensuring food security. Springer, New Delhi, pp 223-272. https://doi.org/10.1007/978-81-322-2199-9_12

14. Stigter CJ, Ofori E (2014) What climate change means for farmers in Africa: a triptych review middle panel: introductional matters and consequences of global warming for African farmers. Afr J Food Agric Nutr Dev 14(1):8428-8444

15. Alberts B (2017) Science for life. Science 355(6332):1353. https://doi.org/10.1126/science.aan2924

16. Soussana J-F, Lutfalla S, Ehrhardt F, Rosenstock T, Lamanna C, Havlík P, Richards M, Wollenberg E, Chotte J-L, Torquebiau E, Ciais P, Smith P, Lal R (2019) Matching policy and science: rationale for the ' 4 per 1000 - soils for food security and climate' initiative. Soil Tillage Res 188:3-15. https://doi.org/10.1016/j. still.2017.12.002

17. National Research C (2002) Abrupt climate change: inevitable surprises. National Academies Press, Washington, D.C.

18. Thompson C, Mendoza CA, Devito KJ (2017) Potential influence of climate change on ecosystems within the Boreal Plains of Alberta C8-HYP-16-0499.R1. Hydrol Process 31(11):2110-2124. https://doi.org/10.1002/hyp.11183

19. Roberts JW, Tesfamichael S, Gebreslasie M, van Aardt J, Ahmed FB (2007) Forest structural assessment using remote sensing technologies: an overview of the current state of the art. Southern Hemis For J 69(3):183-203. https://doi.org/10.2989/shfj. 2007.69.3.8.358

20. Albrich K, Rammer W, Seidl R (2020) Climate change causes critical transitions and irreversible alterations of mountain forests. Global Change Biol. https://doi.org/10.1111/gcb.15118

21. Pedersen UB, Stendel M, Midzi N, Mduluza T, Soko W, Stensgaard A-S, Vennervald BJ, Mukaratirwa S, Kristensen TK (2014) Modelling climate change impact on the spatial distribution of fresh water snails hosting trematodes in Zimbabwe. Parasit Vectors 7(1):1-26

22. Sande S, Zimba M, Chinwada P, Takundwa Masendu H, Mberikunshe J, Makuwaza A (2016) A review of new challenges and prospects for malaria elimination in Mutare and Mutasa Districts, Zimbabwe. Malar J 15:1-9

23. Haines A, Ebi K (2019) The imperative for climate action to protect health. N Engl J Med 380(3):263-273. https://doi.org/ 10.1056/NEJMra1807873

24. Kawamoto M, Kanie N (2020) Engaging business: the UN sustainable development goals and climate change. In: International development and the environment. Springer, pp 47-54

25. Zhenmin L, Espinosa P (2019) Tackling climate change to accelerate sustainable development. Nat Clim Change 9(7):494-496. https://doi.org/10.1038/s41558-019-0519-4

26. Silva JA (2019) Climate change. Progress on the United Nations sustainable development goals 6 and 7. Revista Espacios 40:28

27. Biermann F, Kanie N, Kim RE (2017) Global governance by goal-setting: the novel approach of the UN sustainable development goals. Curr Opin Environ Sustain 26-27:26-31. https://doi.org/10.1016/j.cosust.2017.01.010

28. Hoegh-Guldberg O, Jacob D, Taylor M, Bindi M, Brown S, Camilloni I, Diedhiou A, Djalante R, Ebi K, Engelbrecht F, Guiot K, Hijioka Y, Mehrotra S, Payne A, Seneviratne S, Thomas A, Warren R, Zhou G, Halim S, Achlatis M, Alexander L, Allen $M$, Berry $P$, Boyer $C$, Brilli L, Buckeridge $M$, Cheung W, Craig $M$, Ellis N, Evans J, Fisher H, Fraedrich K, Fuss S, Ganase A, Gattuso J, Greve P, Guillen T, Hanasaki N, Hasegawa T, Hayes $K$, Hirsch $A$, Jones $C$, Jung $T$, Kanninen $M$, Krinner G, Lawrence $D$, Lenton $T$, Ley $D$, Liveman $D$, Mahowald $N$, Mclnnes $K$, Meissner K, Millar R, Mintenbeck K, Mitchell D, Mix A, Notz D, Nurse L, Okem A, Olsson L, Oppenheimer M, Paz S, Peterson J, Petzold J, Preuschmann S, Rahman M, Rogelj J, Scheuffele $H$, Schleussner CF, Scott D, Seferian R, Sillmann J, Singh C, Slade R, Stephenson K, Stephenson T, Sylla M, Tebboth M, Tschakert $P$, Vautard R, Wartenburger R, Wehner M, Weyer N, Whyte F, Yohe G, Zhang X, Zougmore R (2018) Chapter 3: Impacts of $1.50 \mathrm{C}$ global warming on natural and human systems. In: Global warming of $1.50 \mathrm{C}$ an IPCC special report on the impacts of global warming of $1.50 \mathrm{C}$ above pre-industrial levels and related global greenhouse gas emission pathways, in the context of strengthening the global response to the threat of climate change. Intergovernmental Panel on Climate Change

29. First PJ (2019) Global Warming of 1.5 C An IPCC special report on the impacts of global warming of $1.5 \mathrm{C}$ above pre-industrial 
levels and related global greenhouse gas emission pathways, in the context of strengthening the global response to the threat of climate change. Sustainable Development, and Efforts to Eradicate Poverty 1

30. Gumindoga W, Rientjes THM, Haile A, Makurira H, Reggiani P (2017) Performance of bias correction schemes for CMORPH rainfall estimates in the Zambezi River Basin. Hydrol Earth Syst Sci. https://doi.org/10.5194/hess-2017-385

31. Scholes RJ, Scholes M, Lucas M (2015) Climate change: briefings from Southern Africa. Wits University Press, Johannesburg

32. Lemos MC, Rood RB (2010) Climate projections and their impact on policy and practice. Wiley Interdisci Rev Climate Change 1(5):670-682. https://doi.org/10.1002/wcc.71

33. Rodo X, Comin F (2003) Global climate: current research and uncertainties in the climate system. Springer, New York

34. Ahmadalipour A, Moradkhani H, Castelletti A, Magliocca N (2019) Future drought risk in Africa: integrating vulnerability, climate change, and population growth. Sci Total Environ 662:672-686. https://doi.org/10.1016/j.scitotenv.2019.01.278

35. Morioka Y, Engelbrecht F, Behera SK (2015) Potential sources of decadal climate variability over Southern Africa. J Clim 28(22):8695-8709. https://doi.org/10.1175/jcli-d-15-0201.1

36. Giugni M, Simonis I, Bucchignani E, Capuano P, De Paola F, Engelbrecht F, Mercogliano P, Topa ME (2015) The impacts of climate change on African cities. In: Urban vulnerability and climate change in Africa. Springer, pp 37-75

37. Daron JD (2014) Regional climate message: Southern Africa (trans: (CSAG) CSAG, Town UoC). Scientific report from the CARIAA Adaptation at Scale in Semi-Arid Regions (ASSAR) Project. CARIAA and ASSAR, Rondebosch, Cape Town (South Africa)

38. Grab S, Nash D (2009) Documentary evidence of climate variability during cold seasons in Lesotho, Southern Africa, 18331900, vol 34. https://doi.org/10.1007/s00382-009-0598-4

39. Neukom R, Nash DJ, Endfield GH, Grab SW, Grove CA, Kelso C, Vogel CH, Zinke J (2014) Multi-proxy summer and winter precipitation reconstruction for southern Africa over the last 200 years. Clim Dyn 42(9):2713-2726. https://doi.org/10.1007/ s00382-013-1886-6

40. Zengeya F, Murwira A, de Garine-Wichatitsky M (2011) An IKONOS-based comparison of methods to estimate cattle home ranges in a semi-arid landscape of southern Africa. Int J Remote Sens 32(22):7805-7826. https://doi.org/10.1080/01431 161.2010 .527866

41. Van Wyk J-A (1998) Towards water security in Southern Africa. Afr Secur Rev 7(2):59-68

42. Emmanuel K (2019) Environmental and climate change in Africa: global drought and local environmental infrastructure. In: Environmental change and African Societies. Brill, Leiden, The Netherlands, pp 71-97. https://doi.org/10.1163/97890 04410848_005

43. Eccles $\mathrm{R}$, Zhang $\mathrm{H}$, Hamilton $\mathrm{D}$ (2019) A review of the effects of climate change on riverine flooding in subtropical and tropical regions. J Water Clim Change 10(4):687-707. https://doi.org/10. 2166/wcc.2019.175

44. Randall DA, Wood RA, Bony S, Colman R, Fichefet T, Fyfe J, Kattsov V, Pitman A, Shukla J, Srinivasan J, Stouffer RJ, Sumi A, Taylor KE (2007) Climate models and their evaluation. In: Climate change 2007: the physical science basis. contribution of working Group I to the fourth assessment report of the intergovernmental panel on climate change. In: Solomon SD, Qin M, Manning $Z$ et al (eds) Cambridge University Press, Cambridge

45. Sévellec F, Sinha B, Skliris N (2016) The rogue nature of hiatuses in a global warming climate. Geophys Res Lett 43(15):81698177. https://doi.org/10.1002/2016gl068950
46. Stouffer R (2006) GFDL's CM2 global coupled climate modelspart 4: idealized climate response. J Climate. https://doi.org/ 10.1175/jcli3632.1

47. Engelbrecht CJ, Engelbrecht FA (2016) Shifts in Köppen-Geiger climate zones over southern Africa in relation to key global temperature goals. Theor Appl Climatol 123(1):247-261. https://doi.org/10.1007/s00704-014-1354-1

48. Abtew W, Melesse AM (2016) Landscape dynamics, soils and hydrological processes in varied climates. Springer geography. Springer, Cham

49. Farjad B, Gupta A, Razavi S, Faramarzi M, Marceau JD (2017) An integrated modelling system to predict hydrological processes under climate and land-use/cover change scenarios. Water. https://doi.org/10.3390/w9100767

50. Mimikou M, Kouvopoulos Y, Cavadias G, Vayianos N (1991) Regional hydrological effects of climate change. J Hydrol 123(1):119-146. https://doi.org/10.1016/0022-1694(91) 90073-Q

51. Abiodun BJ, Adegoke J, Abatan AA, Ibe CA, Egbebiyi TS, Engelbrecht F, Pinto I (2017) Potential impacts of climate change on extreme precipitation over four African coastal cities. Clim Change 143(3):399-413. https://doi.org/10.1007/ s10584-017-2001-5

52. Murwira A, Skidmore AK (2006) Monitoring change in the spatial heterogeneity of vegetation cover in an African savanna. Int J Remote Sens 27(11):2255-2269. https://doi.org/10.1080/ 01431160500396683

53. Maina J, de Moel H, Zinke J, Madin J, McClanahan T, Vermaat JE (2013) Human deforestation outweighs future climate change impacts of sedimentation on coral reefs

54. Wanders N, Wada Y (2014) Human and climate impacts on the 21st century hydrological drought. J Hydrol 526:208-220

55. Nešić K (2018) Mycotoxins-climate impact and steps to prevention based on prediction. Acta Vet 68(1):1-15. https://doi.org/ 10.2478/acve-2018-0001

56. Creese A, Pokam W, Washington R, Todd M, Reason C, Hart N, Blamey R, Kolusu S, Desbiolles F, James R, Munday C, Jack C, Wolski P, Pinto I, Indasi V, Hartley A, Rowell D, Janicot S, Guichard F, Macadam I, Taylor C, Parker DJ, Senior C, Turner A, Vosper $S$, Graham R, Araujo J, Zinyengere N, Marsham J, Kane N, Sul$\tan B$, Tall L, Visman E, Fox G (2016) Africa's climate: Helping decision-makers make sense of climate information. Future Climate for Africa (FCFA), Capetown

57. Zscheischler J, Westra $S$, van den Hurk BJJM, Seneviratne $S I$, Ward PJ, Pitman A, AghaKouchak A, Bresch DN, Leonard M, Wahl T, Zhang X (2018) Future climate risk from compound events. Nat Clim Change 8(6):469-477. https://doi.org/10.1038/ s41558-018-0156-3

58. Eckstein D, Künzel V, Schäfer L, Winges M (2019) Global climate risk index 2020. Germanwatch, Bonn

59. Mishra VN, Rai PK, Mohan K (2014) Prediction of land use changes based on land change modeler (LCM) using remote sensing: a case study of Muzaffarpur (Bihar), India. J Geogr Inst Jovan Cvijic' SASA 64(1):111-127

60. Khare D, Patra D, Mondal A, Kundu S (2015) Impact of landuse/ land cover change on run-off in a catchment of Narmada river in India. Appl Geom 7(1):23

61. Nie W, Yuan Y, Kepner W, Nash MS, Jackson M, Erickson C (2011) Assessing impacts of landuse and landcover changes on hydrology for the upper San Pedro watershed. J Hydrol 407(1-4):105-114. https://doi.org/10.1016/j.jhydrol.2011.07. 012

62. Boongaling CGK, Faustino-Eslava DV, Lansigan FP (2018) Modeling land use change impacts on hydrology and the use of landscape metrics as tools for watershed management: the case of an ungauged catchment in the Philippines. Land Use 
Policy 72:116-128. https://doi.org/10.1016/j.landusepol.2017. 12.042

63. Birhanu A, Masih I, van der Zaag P, Nyssen J, Cai X (2019) Impacts of land use and land cover changes on hydrology of the Gumara catchment, Ethiopia. Phys Chem Earth Parts A/B/C 112:165-174. https://doi.org/10.1016/j.pce.2019.01.006

64. Gebrehiwot SG, Di Baldassarre G, Bishop K, Halldin S, Breuer L (2019) Is observation uncertainty masking the signal of land use change impacts on hydrology? J Hydrol 570:393-400. https://doi.org/10.1016/j.jhydrol.2018.12.058

65. Liu J, Dietz T, Carpenter SR, Alberti M, Folke C, Moran E, Pell AN, Deadman P, Kratz T, Lubchenco J, Ostrom E, Ouyang Z, Provencher W, Redman CL, Schneider SH, Taylor WW (2007) Complexity of coupled human and natural systems. Science 317(5844):1513-1516. https://doi.org/10.1126/science.11440 04

66. Werner BT, McNamara DE (2007) Dynamics of coupled humanlandscape systems. Geomorphology 91(3-4):393-407. https:// doi.org/10.1016/j.geomorph.2007.04.020

67. Nguyen HH, Recknagel F, Meyer W, Frizenschaf J, Shrestha MK (2017) Modelling the impacts of altered management practices, land use and climate changes on the water quality of the Millbrook catchment-reservoir system in South Australia. J Environ Manag 202:1-11. https://doi.org/10.1016/j.jenvm an.2017.07.014

68. Yan R, Cai Y, Li C, Wang X, Liu Q (2019) Hydrological responses to climate and land use changes in a watershed of the Loess Plateau, China. Sustainability 11(5):1443. https://doi.org/10. 3390/su11051443

69. Pokhrel Y, Burbano M, Roush J, Kang H, Sridhar V, Hyndman DW (2018) A review of the integrated effects of changing climate, land use, and dams on Mekong river hydrology. Water 10(3):266. https://doi.org/10.3390/w10030266

70. Bhatasara S (2017) Rethinking climate change research in Zimbabwe. J Environ Stud Sci 7(1):39-52. https://doi.org/10. 1007/s13412-015-0298-9

71. Brazier A (2015) Climate Change in Zimbabwe: facts for planners and decision makers. Konrad-adenauer-stiftung, Harare

72. Haddaway NR, Collins AM, Coughlin D, Kirk S (2015) The role of Google Scholar in evidence reviews and its applicability to grey literature searching. PLoS ONE 10:9. https://doi.org/ 10.1371/journal.pone.0138237

73. Perkins KM, Munguia N, Moure-Eraso R, Delakowitz B, Giannetti BF, Liu G, Nurunnabi M, Will M, Velazquez L (2018) International perspectives on the pedagogy of climate change. J Clean Prod 200:1043-1052. https://doi.org/10.1016/j.jclepro. 2018.07.296

74. Nichols A, Maynard V, Goodman B, Richardson J (2020) Health, climate change and sustainability: a systematic review and thematic analysis of the literature. Environ Health Insights 3:1. https://doi.org/10.1177/EHI.S3003

75. IPCC (2007) Climate change 2007: impacts, adaptation and vulnerability. Contribution of working group II to the fourth assessment report of the intergovernmental panel on climate change. Cambridge University, Cambridge

76. Letcher TM (2009) Climate change: observed impacts on planet earth. Elsevier, Amsterdam

77. Li C, Sun Y, Zwiers F, Wang D, Zhang X, Chen G, Wu H (2020) Rapid warming in summer wet bulb globe temperature in China with human-induced climate change. J Clim. https:// doi.org/10.1175/jcli-d-19-0492.1

78. Nica A, Popescu A, Ibanescu D-C (2019) Human influence on the climate system. Curr Trends Nat Sci 8(15):209-215

79. Huber RA (2020) The role of populist attitudes in explaining climate change skepticism and support for environmental protection. Environ Polit. https://doi.org/10.1080/09644016. 2019.1708186

80. Dunlap RE, McCright AM (2008) A widening gap: republican and democratic views on climate change. Environ Sci Policy Sustain Dev 50(5):26-35. https://doi.org/10.3200/envt.50.5. 26-35

81. Antonio RJ, Brulle RJ (2011) The unbearable lightness of politics: climate change denial and political polarization. Sociol Q 52(2):195-202. https://doi.org/10.1111/j.1533-8525.2011. 01199.x

82. McCright AM, Dunlap RE, Marquart-Pyatt ST (2016) Political ideology and views about climate change in the European Union. Environ Polit 25(2):338-358. https://doi.org/10.1080/09644016. 2015.1090371

83. Dunlap RE, McCright AM, Yarosh JH (2016) The political divide on climate change: partisan polarization widens in the US. Environ Sci Policy Sustain Dev 58(5):4-23. https://doi.org/10. 1080/00139157.2016.1208995

84. Ferraro AJ, Collins M, Lambert FH (2015) A hiatus in the stratosphere? Nat Clim Change 5(6):497-498

85. Yan X-H, Boyer T, Trenberth K, Karl TR, Xie S-P, Nieves V, Tung K-K, Roemmich D (2016) The global warming hiatus: slowdown or redistribution? C8-2016EF000417. Earth's Future 4(11):472482. https://doi.org/10.1002/2016ef000417

86. IPCC (2019) Climate change and land: an IPCC special report on climate change, desertification, land degradation, sustainable land management, food security, and greenhouse gas fluxes in terrestrial ecosystems. Intergovernmental Panel on Climate Change

87. IPCC (2018) Global warming of $1.5^{\circ} \mathrm{C}$. An IPCC special report on the impacts of global warming of $1.5^{\circ} \mathrm{C}$ above pre-industrial levels and related global greenhouse gas emission pathways, in the context of strengthening the global response to the threat of climate change, sustainable development, and efforts to eradicate poverty. Intergovernmental Panel on Climate Change

88. Hulme $\mathrm{M}(2016) 15^{\circ} \mathrm{C}$ and climate research after the Paris Agreement. Nat Clim Change 6(3):222-224. https://doi.org/ 10.1038/nclimate2939

89. Stocker TF, D. Qin GK, Plattner LV, Alexander SK, Allen NL, Bindoff FM, Bréon JA, Church U, Cubasch S, Emori PF, Friedlingstein P, Gillett N, Gregory JM, Hartmann DL, Jansen E, Kirtman B, Knutti R, Krishna Kumar PL, Marotzke J, Masson-Delmotte V, Meehl GA, Mokhov, Piao S, Ramaswamy V, Randall MR, Rojas M, Sabine C, Shindell D, Talley LD, Vaughan DG, Xie SP (2013) Technical summary. In: Climate change 2013: the physical science basis. contribution of working group I to the fifth assessment report of the intergovernmental panel on climate change. Cambridge University, Cambridge

90. WaterNet (2003) The challenge of integrated water resource management for improved rural livelihoods: managing risk, mitigating drought and improving water productivity in the water scarce Limpopo Basin: proposal to the challenge program on water and food. Harare, Zimbabwe

91. IPCC (2001) IPCC 3rd Assessment Report-Climate Change 2001: Working Group II: impacts, adaptation and vulnerability, contribution of Working Group II to the third assessment report of the intergovernmental panel on climate change. Cambridge

92. IPCC (2014) Climate change 2013: the physical science basis: Working Group I contribution to the Fifth assessment report of the Intergovernmental Panel on Climate Change. Cambridge University Press, New York

93. Tollefson J (2018) IPCC says limiting global warming to 1.5 [degrees]C will require drastic action, vol 562

94. Miller B, Croft J (2018) Planet has only until 2030 to stem catastrophic climate change, experts warn. World 8 
95. Cozier M (2017) The US withdrawal from the Paris Agreement: a global perspective. Greenhouse Gases Sci Technol 7(5):774777. https://doi.org/10.1002/ghg.1736

96. Nong D, Siriwardana M (2018) Effects on the U.S. economy of its proposed withdrawal from the Paris Agreement: a quantitative assessment. Energy 159:621-629. https://doi.org/10. 1016/j.energy.2018.06.178

97. Zhang H-B, Dai H-C, Lai H-X, Wang W-T (2017) U.S withdrawal from the Paris Agreement: reasons, impacts, and China's response. Adv Clim Change Res 8(4):220-225. https://doi.org/ 10.1016/j.accre.2017.09.002

98. Caspi G, Shalit U, Kristensen SL, Aronson D, Caspi L, Rossenberg O, Shina A, Caspi O (2020) Climate effect on COVID-19 spread rate: an online surveillance tool. medR xiv:2020.2003.2026.20044727. https://doi.org/10.1101/2020. 03.26 .20044727

99. O'Reilly K, Auzenbergs M, Jafari Y, Liu Y, Flasche S, Lowe R (2020) Effective transmission across the globe: the role of climate in COVID-19 mitigation strategies. Centre for Mathematical Modelling of Infectious Diseases London School of Hygiene and tropical Medicine Status: under-review| First online: 25-03

100. Ficetola GF, Rubolini D (2020) Climate affects global patterns of COVID-19 early outbreak dynamics. medR xiv:2020.2003.2023.20040501. https://doi.org/10.1101/2020. 03.23 .20040501

101. Xia J, Ning L, Wang Q, Chen J, Wan L, Hong S (2017) Vulnerability of and risk to water resources in arid and semi-arid regions of West China under a scenario of climate change. Clim Change 144(3):549-563. https://doi.org/10.1007/s10584-016-1709-y

102. Kimani SK, Esilaba AO, Njeru PNM, Miriti JM, Lekasi JK, Koala $S$ (2015) Improving livelihoods in semi-arid regions of Africa through reduced vulnerability to climate variability and promotion of climate resilience. In: Adapting African agriculture to climate change. Springer, pp 25-33. https://doi.org/10.1007/ 978-3-319-13000-2_2

103. SADC (2011) Climate change adaptation in SADC: strategy for the water sector., 1 edn. SADC Secretariat, Gaborone, Botswana

104. Fakhruddin B, Boylan K, Wild A, Robertson R (2020) Chapter 12-Assessing vulnerability and risk of climate change. In: Sillmann J, Sippel S, Russo S (eds) Climate extremes and their implications for impact and risk assessment. Elsevier, pp 217241. https://doi.org/10.1016/B978-0-12-814895-2.00012-4

105. de Sherbinin A, Bukvic A, Rohat G, Gall M, McCusker B, Preston $B$, Apotsos A, Fish C, Kienberger S, Muhonda P, Wilhelmi O, Macharia D, Shubert W, Sliuzas R, Tomaszewski B, Zhang S (2019) Climate vulnerability mapping: a systematic review and future prospects. WIREs Clim Change 10(5):e600. https://doi. org/10.1002/wcc.600

106. Shah KU, Dulal HB, Awojobi MT (2019) Food security and livelihood vulnerability to climate change. Food Security in Small Island States 219

107. Berrang-Ford L, Ford JD, Paterson J (2011) Are we adapting to climate change? Glob Environ Change 21(1):25-33. https://doi. org/10.1016/j.gloenvcha.2010.09.012

108. Anwar MR, Liu DL, Macadam I, Kelly G (2013) Adapting agriculture to climate change: a review. Theor Appl Climatol 113(1):225-245. https://doi.org/10.1007/s00704-012-0780-1

109. Lennard CJ, Nikulin G, Dosio A, Moufouma-Okia W (2018) On the need for regional climate information over Africa under varying levels of global warming. Environ Res Lett 13(6):060401

110. Brown D, Dodman D, Zvigadza S (2013) Climate change responses in Zimbabwe local actions and national policy. International Institute for Environment and Development

111. Jack C, Wolski P, Pinto I, Indasi V (2016) Future climate for Africa: Southern Africa burning questions-climate science and refining the models. Future climate for Africa (FCFA), Cape Town
112. Magadza CHD (1994) Climate change: some likely multiple impacts in Southern Africa. Food Policy 19(2):165-191. https:// doi.org/10.1016/0306-9192(94)90068-X

113. Anderson CM, Weber CL, Fabricius C, Glew L, Opperman JJ, Pacheco P, Pendleton LH, Thau D, Vermeulen SJ, Shaw MR (2019) Planning for change: conservation-related impacts of climate overshoot. Bioscience. https://doi.org/10.1093/biosci/ biz141

114. ZCHPC (2015) Supercomputing: Zimbabwe centre for high performance computing (ZCHPC) CLUSTER FEATURES. Government of Zimbabwe. http://www.zchpc.ac.zw/. Accessed $28 \mathrm{Apr}$ 2020

115. Unganai LS (1996) Historic and future climatic change in Zimbabwe. Clim Res 137-145

116. Mazvimavi $D(2010)$ Investigating changes over time of annual rainfall in Zimbabwe. Hydrol Earth Syst Sci 14(12):2671-2679. https://doi.org/10.5194/hess-14-2671-2010

117. Unganai LS (1992) Changes in Zimbabwe's rainfall regime and the effect on climatological means ('normals'). In: 5th International meeting on statistical climatology, pp 22-26

118. Unganai L, Mason S (2001) Spatial characterization of Zimbabwe summer rainfall during the period 1920-1996. S Afr J Sci 97(9-10):425-431

119. Mamombe V, Kim W, Choi Y-S (2017) Rainfall variability over Zimbabwe and its relation to large-scale atmosphere-ocean processes. Int J Climatol 37(2):963-971. https://doi.org/10. $1002 /$ joc. 4752

120. Unganai LS, Mason SJ (2002) Long-range predictability of Zimbabwe summer rainfall. Int J Climatol 22(9):1091-1103. https:// doi.org/10.1002/joc.786

121. Thierfelder C, Wall PC (2010) Investigating conservation agriculture (CA) systems in Zambia and Zimbabwe to mitigate future effects of climate change. J Crop Improv 24(2):113-121

122. Ngwenya B, Oosthuizen J, Cross M, Frimpong K (2018) Emerging heat-related climate change influences; a public health challenge to health care practitioners and policy makers: insight from Bulawayo, Zimbabwe. Int J Disast Risk Reduc 27:596-601. https://doi.org/10.1016/j.ijdrr.2017.10.012

123. Gutsa I (2014) Climate change and policy making in Zimbabwe. In search of evidence based policy making? Acta Universitaria 24(6):21-28

124. Sokona Y, Denton $F$ (2001) Climate change impacts: can Africa cope with the challenges? Clim Policy 1(1):117-123

125. Moyo M, Dorward $P$, Craufurd $P$ (2017) Characterizing long term rainfall data for estimating climate risk in semi-arid Zimbabwe. In: Climate change adaptation in Africa. Springer, pp 661-675

126. Dlamini S, Nhapi I, Gumindoga W, Nhiwatiwa T, Dube T (2016) Assessing the feasibility of integrating remote sensing and insitu measurements in monitoring water quality status of Lake Chivero, Zimbabwe. Phys Chem Earth 93:2-11

127. Gordon HB, O'Farrell SP (1997) Transient climate change in the CSIRO coupled model with dynamic sea ice. Mon Weather Rev 125(5):875-908

128. Kuri F, Murwira A, Murwira KS, Masocha M (2014) Predicting maize yield in Zimbabwe using dry dekads derived from remotely sensed Vegetation Condition Index. Int J Appl Earth Obs Geoinf 33:39-46. https://doi.org/10.1016/j.jag.2014.04.021

129. Unganai LS (1997) Surface temperature variation over Zimbabwe between 1897 and 1993. Theor Appl Climatol 56(1):89101. https://doi.org/10.1007/bf00863786

130. Brown D, Chanakira RR, Chatiza K, Dhliwayo M, Dodman D, Masiiwa M, Muchadenyika D, Mugabe P, Zvigadza S (2012) Climate change impacts, vulnerability and adaptation in Zimbabwe. International Institute for Environment and Development, London 
131. Watson RT, Zinyowera MC, Moss RH, Intergovernmental panel on climate change. Working G, II (1998) The regional impacts of climate change: an assessment of vulnerability. Cambridge University Press

132. Allison EH, Perry AL, Badjeck MC, Neil AW, Brown K, Conway D, Halls AS, Pilling GM, Reynolds JD, Andrew NL (2009) Vulnerability of national economies to the impacts of climate change on fisheries. Fish Fish 10(2):173-196

133. Moyo EN, Nangombe SS (2015) Southern Africa's 2012-13 violent storms: role of climate change. Proc IUTAM 17:69-78. https://doi.org/10.1016/j.piutam.2015.06.011

134. Fischer G, Shah M, Tubiello FN, Van Velhuizen H (2005) Socioeconomic and climate change impacts on agriculture: an integrated assessment, 1990-2080. Philos Trans R Soc B Biol Sci 360(1463):2067-2083

135. Beniston M, Verstraete MM (2001) Remote sensing and climate modeling: synergies and limitations. Advances in global change research. Springer, Netherlands

136. Turner DP, Ollinger SV, Kimball JS (2004) Integrating remote sensing and ecosystem process models for landscape- to regional-scale analysis of the carbon cycle. Bioscience 54(6):573-584

137. Gandhi GM, Parthiban S, Thummalu N, Christy A (2015) Ndvi: vegetation change detection using remote sensing and gis-a case study of Vellore district. Proc Comput Sci 57:1199-1210. https://doi.org/10.1016/j.procs.2015.07.415

138. Suryabhagavan KV (2017) GIS-based climate variability and drought characterization in Ethiopia over three decades. Weather Clim Extremes 15:11-23. https://doi.org/10.1016/j. wace.2016.11.005

139. Twumasi YA, Merem EC, Ayala-Silva T, Osei A, Petja BM, Alexander K (2017) Techniques of remote sensing and GIS as tools for visualizing impact of climate change-induced flood in the Southern African region. Am J Clim Change 6(02):306

140. Muhire I, Ahmed F, Abutaleb K (2015) Relationships between Rwandan seasonal rainfall anomalies and ENSO events. Theor Appl Climatol 122(1):271-284. https://doi.org/10.1007/ s00704-014-1299-4

141. Corbett JD, Carter SE (1996) Using GIS to enhance agricultural planning: The example of inter-seasonal rainfall variability in Zimbabwe. Trans GIS 1(3):207-218. https://doi.org/10.1111/j. 1467-9671.1996.tb00045.x

142. Mabaso MLH, Vounatsou P, Midzi S, Da Silva J, Smith T (2006) Spatio-temporal analysis of the role of climate in inter-annual variation of malaria incidence in Zimbabwe. Int J Health Geogr 5:20

143. Mushore TD, Dube T, Manjowe M, Gumindoga W, Chemura A, Rousta I, Odindi J, Mutanga O (2019) Remotely sensed retrieval of Local Climate Zones and their linkages to land surface temperature in Harare metropolitan city, Zimbabwe. Urban Clim 27:259-271. https://doi.org/10.1016/j.uclim.2018.12.006

144. Gumindoga W, Makurira H, Phiri M, Nhapi I (2016) Estimating runoff from ungauged catchments for reservoir water balance in the Lower Middle Zambezi Basin. Water SA 42(4):641-649

145. Chikodzi D (2013) Remote sensing based unravelling of landcover and groundwater scenarios relationships for the middle save sub catchment of south eastern Zimbabwe. Am J Water Resour 1(3):45-50. https://doi.org/10.12691/ajwr-1-3-5

146. Kamusoko C, Aniya M (2009) Hybrid classification of Landsat data and GIS for land use/cover change analysis of the Bindura district, Zimbabwe. Int J Remote Sens 30(1):97-115. https://doi. org/10.1080/01431160802244268

147. Mpala SC, Gagnon AS, Mansell MG, Hussey SW (2016) The hydrology of sand rivers in Zimbabwe and the use of remote sensing to assess their level of saturation. Phys Chem Earth 93:24-36
148. Flato G, Marotzke J, Abiodun B, Braconnot P, Chou SC, Collins WJ, Cox P, Driouech F, Emori S, Eyring V, Forest C, Gleckler $\mathrm{P}$, Guilyardi E, Jakob C, Kattsov V, Reason C, Rummukaines M (2013) Evaluation of climate models. In: Climate change 2013: the physical science basis. Contribution of working group I to the fifth assessment report of the intergovernmental panel on climate change. In: make_name_string expected hash $\mathrm{r}$ (ed) Climate change 2013. Assessment reports of IPCC. Cambridge University Press, pp 741-866

149. Delworth TL, Rosati A, Anderson W, Adcroft AJ, Balaji V, Benson R, Dixon K, Griffies SM, Lee H-C, Pacanowski RC, Vecchi GA, Wittenberg AT, Zeng F, Zhang R (2012) Simulated climate and climate change in the GFDL CM2.5 high-resolution coupled climate model. J Clim 25(8):2755-2781. https://doi.org/10.1175/ jcli-d-11-00316.1

150. Watanabe $S$, Hajima T, Sudo K, Nagashima T, Takemura T, Okajima $\mathrm{H}$, Nozawa T, Kawase $\mathrm{H}$, Abe M, Yokohata T, Ise T, Sato $\mathrm{H}_{\text {, }}$ Kato E, Takata K, Emori S, Kawamiya M (2011) MIROC-ESM 2010: model description and basic results of CMIP5-20c3m experiments. Geosci Model Dev 4(4):845-872. https://doi.org/10. 5194/gmd-4-845-2011

151. Williams KD, Copsey D, Blockley EW, Bodas-Salcedo A, Calvert D, Comer R, Davis P, Graham T, Hewitt HT, Hill R, Hyder P, Ineson S, Johns TC, Keen AB, Lee RW, Megann A, Milton SF, Rae JGL, Roberts MJ, Scaife AA, Schiemann R, Storkey D, Thorpe L, Watterson IG, Walters DN, West A, Wood RA, Woollings T, Xavier PK (2018) The met office global coupled model 3.0 and 3.1 (GC30 and GC31) configurations. J Adv Model Earth Syst 10(2):357-380. https://doi.org/10.1002/2017ms001115

152. Thevakaran A, McGregor JL, Katzfey J, Hoffmann P, Suppiah R, Sonnadara DUJ (2016) An assessment of CSIRO conformal cubic atmospheric model simulations over Sri Lanka. Clim Dyn 46(5):1861-1875. https://doi.org/10.1007/ s00382-015-2680-4

153. Horowitz H, Garland RM, Thatcher MJ, Naidoo M, van der Merwe J, Landman W, Engelbrecht F (2015) First evaluation of the CCAM aerosol simulation over Africa: implications for regional climate modeling. Paper presented at the AGU fall meeting abstracts, 2015/12/1

154. McCarroll D (2015) 'Study the past, if you would divine the future': a retrospective on measuring and understanding Quaternary climate change. J Quat Sci 30(2):154-187. https://doi. org/10.1002/jqs.2775

155. IPCC (2013) Annex I: Atlas of global and regional climate projections. In: van Oldenborgh GJ, Collins M, Arblaster J, Christensen JH, Marotzke J, Power SB, Rummukainen M, Zhou T (eds) Climate change 2013: the physical science basis. Contribution of working group I to the fifth assessment report of the intergovernmental panel on climate change. Cambridge University, Cambridge

156. Pitman AJ, Arneth $A$, Ganzeveld $L$ (2011) Regionalizing global climate models. Int J Climatol 32(3):321-337. https://doi.org/ 10.1002/joc. 2279

157. Ashofteh P-S, Bozorg-Haddad O, Mariño Miguel A (2016) Performance evaluation of a developed hybrid AOGCM model under climate change. J Irrig Drain Eng 142(12):04016068. https://doi. org/10.1061/(asce)ir.1943-4774.0001107

158. Motesharrei S, Rivas J, Kalnay E, Asrar GR, Busalacchi AJ, CahaIan RF, Cane MA, Colwell RR, Feng K, Franklin RS, Hubacek K, Miralles-Wilhelm F, Miyoshi T, Ruth M, Sagdeev R, Shirmohammadi A, Shukla J, Srebric J, Yakovenko VM, Zeng N (2016) Modeling sustainability: population, inequality, consumption, and bidirectional coupling of the earth and human systems. Natl Sci Rev 3(4):470-494

159. Fowler HJ, Blenkinsop S, Tebaldi C (2007) Linking climate change modelling to impacts studies: recent advances in 
downscaling techniques for hydrological modelling. Int J Climatol 27(12):1547-1578. https://doi.org/10.1002/joc.1556

160. Pascoe C, Lawrence BN, Guilyardi E, Juckes M, Taylor KE (2020) Documenting numerical experiments in support of the Coupled Model Intercomparison Project Phase 6 (CMIP6). Geoscientific Model Development 13(5):2149-2167

161. Morim J, Hemer M, Andutta F, Shimura T, Cartwright N (2020) Skill and uncertainty in surface wind fields from general circulation models: intercomparison of bias between AGCM, AOGCM and ESM global simulations. Int J Climatol 40(5):2659-2673. https://doi.org/10.1002/joc.6357

162. Roberts MJ, Baker A, Blockley EW, Calvert D, Coward A, Hewitt $H T$, Jackson LC, Kuhlbrodt T, Mathiot $P$, Roberts CD, Schiemann $R$, Seddon J, Vannière B, Vidale PL (2019) Description of the resolution hierarchy of the global coupled HadGEM3-GC3.1 model as used in CMIP6 HighResMIP experiments. Geosci Model Dev 12(12):4999-5028. https://doi.org/10.5194/gmd-12-4999-2019

163. Andrews MB, Ridley JK, Wood RA, Andrews T, Blockley EW, Booth B, Burke E, Dittus AJ, Florek P, Gray LJ, Haddad S, Hardiman SC, Hermanson L, Hodson D, Hogan E, Jones GS, Knight JR, Kuhlbrodt T, Misios S, Mizielinski MS, Ringer MA, Robson J, Sutton RT (2020) Historical simulations with HadGEM3-GC3.1 for CMIP6. J Adv Model Earth Syst. https://doi.org/10.1029/ $2019 \mathrm{~ms} 001995$

164. Bouwer LM, Aerts JC, Van de Coterlet GM, Van de Giesen N, Gieske A, Mannaerts C (2004) Evaluating downscaling methods for preparing global circulation model (GCM) data for hydrological impact modeling. London, Climate change in contrasting river basins. In: Aerts JC, Droogers P (eds) Evaluating downscaling methods for preparing global circulation model (GCM) data for hydrological impact modeling. Climate change in contrasting river basins. CAB International Publishing, London

165. Hewitson BC, Reason C, Tennant W, Tadross M, Jack C, Mackellar N, Lennard C, Hansingo K, Walawege R, Mdoka M (2004) Regional climate models, vol 2004. Water Research Commission [WRC], pp 23-23

166. Hidalgo HG, Dettinger MD, Cayan DR (2008) Downscaling with constructed analogues: daily precipitation and temperature fields over the United States. Calif Energy Commun PIER Energy Relat Environ Res

167. Dosio A, Panitz H-J, Schubert-Frisius M, Lüthi D (2014) Dynamical downscaling of CMIP5 global circulation models over CORDEX-Africa with COSMO-CLM: evaluation over the present climate and analysis of the added value. Clim Dyn 44(9/10):2637-2661

168. Kalognomou E-A, Lennard C, Shongwe M, Pinto I, Favre A, Kent M, Hewitson B, Dosio A, Nikulin G, Panitz H, Bachner M (2013) A diagnostic evaluation of precipitation in CORDEX models over Southern Africa. J Clim 26(23):9477-9506

169. Landman WA, Kgatuke MJ, Mbedzi M (2006) Skill comparison of some dynamical and empirical downscaling methods for southern Africa from a seasonal climate modelling perspective. Water Research Commission [WRC]

170. Gutowski WJ, Giorgi F, Timbal B, Frigon A, Jacob D, Kang HS, Raghavan K, Lee B, Lennard C, Nikulin G, O'Rourke E, Rixen M, Solman S, Stephenson T, Tangang F (2016) WCRP coordinated regional downscaling experiment (CORDEX): a diagnostic MIP for CMIP6. Geosci Model Dev 9(11):4087-4095. https://doi.org/ 10.5194/gmd-9-4087-2016

171. Delworth T (2006) GFDL's CM2 global coupled climate models-part 1: formulation and simulation characteristics. J Clim. https://doi.org/10.1175/jcli3629.1

172. Randall DA, Wood RA, Bony S, Colman R, Fichefet T, Fyfe J, Kattsov V, Pitman A, Shukla J, Srinivasan J (2007) Climate models and their evaluation. In: Climate change 2007: the physical science basis. Contribution of Working Group I to the fourth assessment report of the IPCC (FAR). Cambridge University Press, pp 589-662

173. Micheli E, Flint L, Flint A, Weiss S, Kennedy M (2012) Downscaling future climate projections to the watershed scale: a North San Francisco bay case study. San Francisco Estuary Watershed Sci 10(4):12

174. Cannon AJ, Sobie SR, Murdock TQ (2015) Bias correction of GCM precipitation by quantile mapping: how well do methods preserve changes in quantiles and extremes? J Clim 28(17):6938-6959. https://doi.org/10.1175/jcli-d-14-00754.1

175. Faramarzi M, Abbaspour KC, Ashraf Vaghefi S, Farzaneh MR, Zehnder AJB, Srinivasan R, Yang H (2012) Modeling impacts of climate change on freshwater availability in Africa. J Hydrol 480:85-101

176. Arora $M$ (2019) Uncertainties in climate change projections. Adv Innov Res 6(2):19

177. Shongwe ME, Lennard C, Liebmann B, Kalognomou E-A, Ntsangwane L, Pinto I (2015) An evaluation of CORDEX regional climate models in simulating precipitation over Southern Africa. Atmos Sci Lett 16(3):199-207

178. Meque A, Abiodun B (2015) Simulating the link between ENSO and summer drought in Southern Africa using regional climate models. Clim Dyn 44(7/8):1881-1900

179. Abiodun BJ, Makhanya N, Petja B, Abatan AA, Oguntunde PG (2019) Future projection of droughts over major river basins in Southern Africa at specific global warming levels. Theoret Appl Climatol 137(3):1785-1799. https://doi.org/10.1007/ s00704-018-2693-0

180. Archer ERM, Engelbrecht FA, Hänsler A, Landman W, Tadross $M$, Helmschrot J (2018) Seasonal prediction and regional climate projections for southern Africa. Klaus Hess Publishers,

181. World Meteorological Organization (1975) Intercomparison of conceptual models used in operational hydrological forecasting, operational hydrology report No. 7. Geneva

182. Refsgaard JC, Knudsen J (1996) Operational validation and intercomparison of different types of hydrological models. Water Resour Res 32(7):2189-2202. https://doi.org/10.1029/ 96 wr00896

183. Engelbrecht F, Adegoke J, Bopape M-J, Naidoo M, Garland R, Thatcher M, McGregor J, Katzfey J, Werner M, Ichoku C, Gatebe $C$ (2015) Projections of rapidly rising surface temperatures over Africa under low mitigation. Environ Res Lett 10(8):085004. https://doi.org/10.1088/1748-9326/10/8/085004

184. Henderson-Sellers A, McGuffie K (2012) The future of the world's climate. Elsevier Science, Amsterdam

185. Salathé EP, Leung LR, Qian Y, Zhang Y (2010) Regional climate model projections for the State of Washington. Clim Change 102(1):51-75. https://doi.org/10.1007/s10584-010-9849-y

186. India MB, Bonillo DL (2013) Detecting and modelling regional climate change. Springer, Berlin

187. Pinto I, Lennard C, Tadross M, Hewitson B, Dosio A, Nikulin G, Panitz H-J, Shongwe ME (2016) Evaluation and projections of extreme precipitation over southern Africa from two CORDEX models. Clim Change 135(3):655-668. https://doi.org/10.1007/ s10584-015-1573-1

188. Kalognomou E-A, Lennard $C$, Shongwe $M$, Pinto I, Favre $A$, Kent M, Hewitson B, Dosio A, Nikulin G, Panitz H-J, Büchner $M$ (2013) A diagnostic evaluation of precipitation in CORDEX models over Southern Africa. J Clim 26(23):9477-9506. https:// doi.org/10.1175/jcli-d-12-00703.1

189. Maúre G, Pinto I, Ndebele-Murisa $M$, Muthige $M$, Lennard C, Nikulin G, Dosio A, Meque A (2018) The southern African climate under $1.5^{\circ} \mathrm{C}$ and $2{ }^{\circ} \mathrm{C}$ of global warming as simulated by CORDEX regional climate models. Environ Res Lett 13(6):065002 
190. Dosio A, Panitz H-J (2016) Climate change projections for CORDEX-Africa with COSMO-CLM regional climate model and differences with the driving global climate models. Clim Dyn 46(5):1599-1625. https://doi.org/10.1007/s00382-015-2664-4

191. Kristensen TK, Stensgaard A-S, Solander K, Mukarartirwa S (2007) Freshwater snail diversity, climate and snail borne diseases in Zimbabwe: a study utilizing GIS and remote sensing. In: The international symposium on geospatial health

192. Lord JS, Hargrove JW, Torr SJ, Vale GA (2018) Climate change and African trypanosomiasis vector populations in Zimbabwe's Zambezi Valley: a mathematical modelling study. PLoS Med 15(10):e1002675. https://doi.org/10.1371/journal.pmed.10026 75

193. Gwitira I, Murwira A, Zengeya FM, Masocha M, Mutambu S (2015) Modelled habitat suitability of a malaria causing vector (Anopheles arabiensis) relates well with human malaria incidences in Zimbabwe. Appl Geogr 60:130-138. https://doi.org/ 10.1016/j.apgeog.2015.03.010

194. Zhu T, Ringler C (2012) Climate change impacts on water availability and use in the Limpopo river basin. Water. https://doi. org/10.3390/w4010063

195. Mahere TS, Mtsambiwa MZ, Chifamba PC, Nhiwatiwa T (2014) Climate change impact on the limnology of Lake Kariba, Zambia-Zimbabwe. Afr J Aquat Sci 39(2):215-221

196. Love D, Uhlenbrook S, Twomlow S, van der Zaag P (2010) Changing hydroclimatic and discharge patterns in the northern Limpopo Basin. Zimbabwe Water SA 36(3):335-350

197. Patt A, Gwata C (2002) Effective seasonal climate forecast applications: examining constraints for subsistence farmers in Zimbabwe. Glob Environ Change 12(3):185-195. https:// doi.org/10.1016/S0959-3780(02)00013-4

198. Sango I, Nhamo G (2014) Climate change trends and environmental impacts in the Makonde Communal Lands, Zimbabwe. South Afr J Sci 111(7/8):1-6

199. Makadho JM (1996) Potential effects of climate change on corn production in Zimbabwe. Climate Res 147-151

200. de Moraes TC, dos Santos VJ, Calijuri ML, Torres FTP (2018) Effects on runoff caused by changes in land cover in a Brazilian southeast basin: evaluation by HEC-HMS and HECGEOHMS. Environ Earth Sci 77(6):250. https://doi.org/10. 1007/s12665-018-7430-6

201. Matarira $\mathrm{CH}$, Kamukondiwa W, Mwamuka FC, Makadho JM, Unganai LS (1996) Vulnerability and adaptation assessments for Zimbabwe. In: Smith JB, Huq S, Lenhart S, Mata LJ, Nemešová I, Toure S (eds) Vulnerability and adaptation to climate change: interim results from the U.S. Country studies program. Springer, Dordrecht, pp 129-140. https://doi.org/ 10.1007/978-94-017-3653-4_6

202. Kondrat'ev KIA, Krapivin VF, Varotsos C (2003) Global carbon cycle and climate change. Environmental sciences. Springer, Berlin

203. Makaudze EM (2005) Do seasonal climate forecasts and crop insurance really matter for smallholder farmers in Zimbabwe: using contingent valuation method and remote sensing applications. The Ohio State University

204. Engelbrecht FA, Marean CW, Cowling RM, Engelbrecht CJ, Neumann FH, Scott L, Nkoana R, O'Neal D, Fisher E, Shook E, Franklin J, Thatcher M, McGregor JL, Van der Merwe J, Dedekind Z, Difford M (2019) Downscaling last glacial maximum climate over southern Africa. Quatern Sci Rev 226:105879. https://doi.org/10.1016/j.quascirev.2019.105879

205. Dosio A (2017) Projection of temperature and heat waves for Africa with an ensemble of CORDEX regional climate models. Clim Dyn 49(1):493-519. https://doi.org/10.1007/ s00382-016-3355-5
206. Abiodun BJ, Abba Omar S, Lennard C, Jack C (2016) Using regional climate models to simulate extreme rainfall events in the Western Cape, South Africa. Int J Climatol 36(2):689705. https://doi.org/10.1002/joc.4376

207. Ki M (2019) Climate change impacts on socioeconomic activities through labor productivity changes considering interactions between socioeconomic and climate systems. J Clean Prod 216:528-541. https://doi.org/10.1016/j.jclepro.2018.12. 127

208. Shakhawat Hossain M, Arshad M, Qian L, Kächele H, Khan I, Din II Islam M, Golam Mahboob M (2020) Climate change impacts on farmland value in Bangladesh. Ecol Ind 112:106181. https://doi.org/10.1016/j.ecolind.2020.106181

209. Boone RB, Conant RT, Sircely J, Thornton PK, Herrero M (2018) Climate change impacts on selected global rangeland ecosystem services. Glob Change Biol 24(3):1382-1393. https:// doi.org/10.1111/gcb.13995

210. Estrada F, Botzen WJW, Tol RSJ (2017) A global economic assessment of city policies to reduce climate change impacts. Nat Clim Change 7(6):403-406. https://doi.org/10.1038/nclim ate3301

211. Ishimwe R, Abutaleb K, Ahmed F (2014) Applications of thermal imaging in agriculture-a review. Adv Remote Sens 3:128-140. https://doi.org/10.4236/ars.2014.33011

212. Ngie A, Ahmed F, Abutaleb K (2014) Remote sensing potential for investigation of maize production: review of literature. South Afr J Geom. https://doi.org/10.4314/sajg.v3i2.4

213. Vicuna S, Dracup JA (2007) The evolution of climate change impact studies on hydrology and water resources in California. Clim Change 82(3):327-350. https://doi.org/10.1007/ s10584-006-9207-2

214. Knowles N, Cayan DR (2002) Potential effects of global warming on the Sacramento/San Joaquin watershed and the San Francisco estuary C8-1891. Geophys Res Lett 29(18):38-34. https:// doi.org/10.1029/2001gl014339

215. LaFontaine JH, Hay LE, Viger RJ, Regan RS, Markstrom SL (2015) Effects of climate and land cover on hydrology in the southeastern U.S.: potential impacts on watershed planning. JAWRA J Am Water Resour Assoc 51(5):1235-1261. https://doi.org/10. 1111/1752-1688.12304

216. Abutaleb K, Ngie A, Darwish A, Ahmed M, Arafat S, Ahmed F (2015) Assessment of urban heat island using remotely sensed imagery over greater cairo. Egypt Adv Remote Sens 4:35-47. https://doi.org/10.4236/ars.2015.41004

217. Christensen JH, Krishna Kumar E, Aldrian S-I, An IFA, Cavalcanti $M$, de Castro W, Dong P, Goswami A, Hall JK, Kanyanga A, Kitoh JK, Lau J, Renwick DB, Stephenson S-P, Xie TZ (2013) Climate phenomena and their relevance for future regional climate change. In: Climate change 2013: the physical science basis. Contribution of working group I to the fifth assessment report of the intergovernmental panel on climate change. Cambridge University, Cambridge

218. Gore M, Abiodun BJ, Kucharski F (2020) Understanding the influence of ENSO patterns on drought over southern Africa using SPEEDY. Clim Dyn 54(1):307-327. https://doi.org/10. 1007/s00382-019-05002-w

219. Manatsa D, Mushore T, Lenouo A (2017) Improved predictability of droughts over southern Africa using the standardized precipitation evapotranspiration index and ENSO. Theor Appl Climatol 127(1):259-274. https://doi.org/10.1007/ s00704-015-1632-6

220. Plagányi É (2019) Climate change impacts on fisheries. Science 363(6430):930. https://doi.org/10.1126/science.aaw5824

221. Powers RP, Jetz W (2019) Global habitat loss and extinction risk of terrestrial vertebrates under future land-use-change 
scenarios. Nat Clim Change 9(4):323-329. https://doi.org/10. 1038/s41558-019-0406-z

222. Tian X, Sohngen B, Kim JB, Ohrel S, Cole J (2016) Global climate change impacts on forests and markets. Environ Res Lett 11(3):035011. https://doi.org/10.1088/1748-9326/11/3/035011

223. Yamba FD, Walimwipi H, Jain S, Zhou P, Cuamba B, Mzezewa C (2011) Climate change/variability implications on hydroelectricity generation in the Zambezi River Basin. Mitig Adapt Strat Glob Change 16(6):617-628. https://doi.org/10.1007/ s11027-011-9283-0

224. Spalding-Fecher $R$, Chapman A, Yamba F, Walimwipi $H$, Kling H, Tembo B, Nyambe I, Cuamba B (2016) The vulnerability of hydropower production in the Zambezi River Basin to the impacts of climate change and irrigation development. Mitig Adapt Strat Glob Change 21(5):721-742. https://doi.org/10. 1007/s11027-014-9619-7

225. Li Y, Pizer WA, Wu L (2019) Climate change and residential electricity consumption in the Yangtze River Delta, China. Proc Natl Acad Sci 116(2):472. https://doi.org/10.1073/pnas.1804667115

226. De Cian E, Sue Wing I (2019) Global energy consumption in a warming climate. Environ Resour Econ 72(2):365-410. https:// doi.org/10.1007/s10640-017-0198-4

227. Rogers DP, Shapiro MA, Brunet G, Cohen JC, Connor SJ, Diallo AA, Elliott W, Haidong $K$, Hales $S$, Hemming $D$, Jeanne I, Lafaye M, Mumba Z, Raholijao N, Rakotomanana F, Teka H, Trtanj J, Whung PY (2010) Health and climate-opportunities. Proc Environ Sci 1:37-54. https://doi.org/10.1016/j.proenv. 2010.09.005

228. Schewe J, Gosling SN, Reyer C, Zhao F, Ciais P, Elliott J, Francois L, Huber V, Lotze HK, Seneviratne SI, van Vliet MTH, Vautard R, Wada Y, Breuer L, Büchner M, Carozza DA, Chang J, Coll M, Deryng D, de Wit A, Eddy TD, Folberth C, Frieler K, Friend AD, Gerten D, Gudmundsson L, Hanasaki N, Ito A, Khabarov N, Kim H, Lawrence P, Morfopoulos C, Müller C, Müller Schmied H, Orth R, Ostberg S, Pokhrel Y, Pugh TAM, Sakurai G, Satoh Y, Schmid E, Stacke T, Steenbeek J, Steinkamp J, Tang Q, Tian H, Tittensor DP, Volkholz J, Wang X, Warszawski L (2019) Stateof-the-art global models underestimate impacts from climate extremes. Nat Commun 10(1):1005. https://doi.org/10.1038/ s41467-019-08745-6

229. von Storch H, Navarra A (2013) Analysis of climate variability: applications of statistical techniques proceedings of an autumn school organized by the commission of the european community on Elba from October 30 to November 6, 1993. Springer Berlin

230. Gwitira I, Murwira A, Shekede MD, Masocha M, Chapano C (2014) Precipitation of the warmest quarter and temperature of the warmest month are key to understanding the effect of climate change on plant species diversity in Southern African savannah. Afr J Ecol 52(2):209-216. https://doi.org/10.1111/aje. 12105

231. Nyabako T, Manzungu E (2012) An assessment of the adaptability to climate change of commercially available maize varieties in Zimbabwe. Environ Nat Resour Res 2(1):32. https://doi.org/ 10.5539/enrr.v2n1p32

232. Unganai LS, Murwira A (2010) Challenges and opportunities for climate change adaptation among smallholder farmers in southeast Zimbabwe. In: 2nd International conference: climate, sustainability and development in semi-arid regions, Ceará Convention Center, Fortaleza, Brazil, pp 16-20

233. Mano R, Nhemachena C (2007) Assessment of the economic impacts of climate change on agriculture in Zimbabwe: a Ricardian approach

234. Utete B, Phiri C, Mlambo SS, Muboko N, Fregene BT (2019) Vulnerability of fisherfolks and their perceptions towards climate change and its impacts on their livelihoods in a peri-urban lake system in Zimbabwe. Environ Dev Sustain 21(2):917-934. https://doi.org/10.1007/s10668-017-0067-x

235. Ncube SP (2010) Reservoir operation under different climate change scenarios: case of Roswa Dam, Bikita District, Zimbabwe. University of Zimbabwe, Harare

236. Ebi KL, Hartman J, Chan N, Mcconnell J, Schlesinger M, Weyant J (2005) Climate suitability for stable Malaria transmission in zimbabwe under different climate change scenarios. Clim Change 73(3):375. https://doi.org/10.1007/s10584-005-6875-2

237. Pilossof R (2016) A brief history of tsetse control methods in Zimbabwe and possible effects of climate change on their distribution. Int J Afr Dev 4(1):8

238. Dube K, Nhamo G (2020) Vulnerability of nature-based tourism to climate variability and change: case of Kariba resort town, Zimbabwe. J Outdoor Recreat Tour 29:100281. https://doi.org/ 10.1016/j.jort.2020.100281

239. Tekleab S, Mohamed YA, Uhlenbrook S, Wenninger J (2014) Hydrologic responses to land cover change: the case of Jedeb mesoscale catchment, Abay/Upper Blue Nile basin, Ethiopia. Hydrol Process 28(20):5149-5161. https://doi.org/10.1002/hyp. 9998

240. Masocha M, Murwira A, Magadza CHD, Hirji R, Dube T (2017) Remote sensing of surface water quality in relation to catchment condition in Zimbabwe. Phys Chem Earth Parts A/B/C 100:13-18. https://doi.org/10.1016/j.pce.2017.02.013

241. Beniston M (2006) Climatic change: implications for the hydrological cycle and for water management. Advances in global change research. Springer, Amsterdam

242. Gwimbi P (2009) Cotton farmers' vulnerability to climate change in Gokwe District (Zimbabwe): Impact and influencing factors. J Disast Risk Stud 2(2):81-92

243. Manyani A, Chagweda K, Mudavanhu C, Chanza N (2017) Indigenous-based practices of adapting to climate change: reflections from Chirumhanzu. Zimbabwe Asian Soc Sci 9(5):23192399. https://doi.org/10.9790/2402-1112015466

244. Unganai LS, Kogan FN (1998) Southern Africa's recent droughts from space. Adv Space Res 21(3):507-511. https://doi.org/10. 1016/S0273-1177(97)00888-0

245. Chingombe W, Pedzisai E, Manatsa D, Mukwada G, Taru P (2015) A participatory approach in GIS data collection for flood risk management, Muzarabani district. Zimbabwe Arab J Geosci 8(2):1029-1040. https://doi.org/10.1007/s12517-014-1265-6

246. Nyanganyura D (1999) Drought and desertification versus climate dynamics in nort-east Zimbabwe. Doctoral dissertation, University of Zimbabwe, Harare

247. Manatsa D, Mukwada G (2012) Rainfall mechanisms for the dominant rainfall mode over Zimbabwe relative to ENSO and/ or IODZM. Sci World J 2012:926310. https://doi.org/10.1100/ 2012/926310

248. Senda T, Descheemaeker KKE, Tui SHK, Masikati P, Sisito G, Crespo O, Francis B (2016) Modeling climate change impacts on livestock productivity in semi-arid Zimbabwe.

249. Salewicz A (1995) Impact of climate change on the operation of Lake Kariba hydropower scheme on the Zambezi river. In: Water resources management in the face of climatic and hydrologic uncertainties. Kluwer Academic Publishers, Dordrecht

250. Beck L, Bernauer T (2011) How will combined changes in water demand and climate affect water availability in the Zambezi river basin? Glob Environ Change 21(3):1061-1072. https://doi. org/10.1016/j.gloenvcha.2011.04.001

251. Gwenzi J, Mashonjowa E, Mafongoya PL, Rwasoka DT, Stigter K (2016) The use of indigenous knowledge systems for short and long range rainfall prediction and farmers' perceptions of science-based seasonal forecasts in Zimbabwe. Int J Clim Change Strat Manag 8(3):440-462. https://doi.org/10.1108/ IJCCSM-03-2015-0032 
252. Cobo JG, Dercon G, Yekeye T, Chapungu L, Kadzere C, Murwira A, Delve R, Cadisch G (2010) Integration of mid-infrared spectroscopy and geostatistics in the assessment of soil spatial variability at landscape level. Geoderma 158(3):398-411. https:// doi.org/10.1016/j.geoderma.2010.06.013

253. Davis R, Hirji R (2014) Climate change and water resources planning, development and management in Zimbabwe, 1st edn. World Bank, Harare

254. Dalu T, Tambara EM, Clegg B, Chari LD, Nhiwatiwa T (2012) Modeling sedimentation rates of Malilangwe reservoir in the southeastern lowveld of Zimbabwe. Appl Water Sci 3(1):133-144. https://doi.org/10.1007/s13201-012-0067-9

255. Dube K, Nhamo G (2018) Climate variability, change and potential impacts on tourism: evidence from the Zambian side of the Victoria Falls. Environ Sci Policy 84:113-123. https://doi.org/10. 1016/j.envsci.2018.03.009

256. Dube K, Nhamo G (2019) Climate change and the aviation sector: a focus on the Victoria Falls tourism route. Environ Dev 29:5-15. https://doi.org/10.1016/j.envdev.2018.12.006

257. Mubaya CP, Mafongoya PL, Jiri O, Mafongoya O, Gwenzi J (2017) Seasonal climate prediction in Zimbabwe using indigenous knowledge systems. Indig Knowl Syst Clim Change Manag Africa 95

258. Soropa G, Gwatibaya S, Musiyiwa K, Rusere F, Mavima GA, Kasasa P (2015) Indigenous knowledge system weather forecasts as a climate change adaptation strategy in smallholder farming systems of Zimbabwe: case study of Murehwa, Tsholotsho and Chiredzi districts. Afr J Agric Res 10(10):1067-1075

259. Chagonda I, Munodawafa A, Mugabe FT, Makuvaro V, Masere P, Murewi CTF (2013) Comparative performance of scientific and indigenous knowledge on seasonal climate forecasts: a case study of Lupane, semi-arid Zimbabwe. Int J Agron Agric Res 3(5):1-9

260. Mugambiwa SS (2018) Adaptation measures to sustain indigenous practices and the use of indigenous knowledge systems to adapt to climate change in Mutoko rural district of Zimbabwe. J Disast Risk Stud 10(1):1-9. https://doi.org/10.4102/ jamba.v10i1.388

261. Manyanhaire $I O$ (2015) Integrating indigenous knowledge systems into climate change interpretation: perspectives relevant to Zimbabwe. Greener J Educ Res 5:27-36

262. Jiri O, Mafongoya PL, Chivenge $P$ (2015) Indigenous knowledge systems, seasonal 'quality' and climate change adaptation in Zimbabwe. Clim Res 66:103-111. https://doi.org/10.3354/cr013 34

263. Xu C-Y (2002) Textbook of hydrologic models (Lärobok i Avrinningsmodeller)

264. Chen R-S, Pi L-C, Hsieh C-C (2005) Application of parameter optimization method for calibrating tank model. JAWRA J Am Water Resour Assoc 41(2):389-402. https://doi.org/10.1111/j. 1752-1688.2005.tb03743.x

265. Oleyiblo JO, Li Z-j (2010) Application of HEC-HMS for flood forecasting in Misai and Wan'an catchments in China. Water Sci Eng 3(1):14-22. https://doi.org/10.3882/j.issn.1674-2370.2010.01. 002

266. Dotson HW (2001) Watershed modeling with HEC-HMS (hydrologic engineering centers-hydrologic modeling system) using spatially distributed rainfall. In: Coping with FLASH FLOods. Springer, pp 219-230

267. Ghoraba SM (2015) Hydrological modeling of the Simly Dam watershed (Pakistan) using GIS and SWAT model. Alex Eng J 54(3):583-594. https://doi.org/10.1016/j.aej.2015.05.018

268. Arnold G, Moriasi N, Gassman W, Abbaspour C, White J, Srinivasan S, Harmel D, van Griensven W, Liew V, Kannan KJ (2012) SWAT: model use, calibration, and validation. Trans ASABE 55(4):1491-1508. https://doi.org/10.13031/2013.42256
269. Chiew FHS, Stewardson MJ, McMahon TA (1993) Comparison of six rainfall-runoff modelling approaches. J Hydrol 147(1):1-36. https://doi.org/10.1016/0022-1694(93)90073-I

270. Sivapalan M, Savenije HHG, Bloschl G, McDonnell JJ, Hrachowitz M, Pomeroy JW, Arheimer B, Blume T, Clark MP, Ehret U, Fenicia F, Freer JE, Gelfan A, Gupta HV, Hughes DA, Hut RW, Montanari A, Pande S, Tetzlaff D, Troch PA, Uhlenbrook S, Wagener T, Winsemius HC, Woods RA, Zehe E, Cudennec C (2013) A decade of predictions in ungauged basins (PUB): a review. Hydrol Sci J Des Sci Hydrol 58(6):1198-1255

271. Jaiswal RK, Ali S, Bharti B (2020) Comparative evaluation of conceptual and physical rainfall-runoff models. Appl Water Sci 10(1):48. https://doi.org/10.1007/s13201-019-1122-6

272. Refsgaard JC (1997) Parameterisation, calibration and validation of distributed hydrological models. J Hydrol 198(1-4):6997. https://doi.org/10.1016/S0022-1694(96)03329-X

273. Uhlenbrook S, Roser S, Tilch N (2004) Hydrological process representation at the meso-scale: the potential of a distributed, conceptual catchment model. J Hydrol 291(3-4):278-296. https://doi.org/10.1016/j.jhydrol.2003.12.038

274. Wooldridge S, Kalma J, Kuczera G (2001) Parameterisation of a simple semi-distributed model for assessing the impact of land-use on hydrologic response. J Hydrol 254(1-4):16-32. https://doi.org/10.1016/S0022-1694(01)00489-9

275. Gao H, Sabo JL, Chen X, Liu Z, Yang Z, Ren Z, Liu M (2018) Landscape heterogeneity and hydrological processes: a review of landscape-based hydrological models. Landscape Ecol 33(9):1461-1480. https://doi.org/10.1007/ s10980-018-0690-4

276. Refsgaard JC, Storm B, Clausen T (2010) Système Hydrologique Europeén (SHE): review and perspectives after 30 years development in distributed physically-based hydrological modelling. Hydrol Res 41(5):355

277. Karvonen $T$, Koivusalo $H$, Jauhiainen $M$, Palko J, Weppling $K$ (1999) A hydrological model for predicting runoff from different land use areas. J Hydrol 217(3-4):253-265. https://doi.org/ 10.1016/S0022-1694(98)00280-7

278. Gal L, Grippa M, Hiernaux P, Peugeot C, Mougin E, Kergoat $L$ (2016) Changes in lakes water volume and runoff over ungauged Sahelian watersheds. J Hydrol 540:1176-1188. https://doi.org/10.1016/j.jhydrol.2016.07.035

279. Finch JW (1990) Location of high-yielding groundwater sites in Zimbabwe by use of remotely sensed data. In: Remote sensing: an operational technology for the mining and petroleum industries. Springer, Dordrecht, pp 147-152. https://doi.org/ 10.1007/978-94-010-9744-4_15

280. Schultz GA, Engman ET (2012) Remote sensing in hydrology and water management. Springer, Berlin

281. Schmugge TJ, Kustas WP, Ritchie JC, Jackson TJ, Rango A (2002) Remote sensing in hydrology. Adv Water Resour 25(8):13671385. https://doi.org/10.1016/S0309-1708(02)00065-9

282. Makhamreh Z (2011) Using remote sensing approach and surface landscape conditions for optimization of watershed management in Mediterranean regions. Phys Chem Earth Parts A/B/C 36(5-6):213-220. https://doi.org/10.1016/j.pce.2010.08. 004

283. Bhavsar PD (1984) Review of remote sensing applications in hydrology and water resources management in India. Adv Space Res 4(11):193-200. https://doi.org/10.1016/02731177(84)90411-3

284. Halvorsen T, Ibsen $\mathrm{H}$ (2015) Knowledge for a sustainable world: a Southern African-Nordic contribution, illustrated, reprint edn. African Minds

285. Thanapakpawin P, Richey J, Thomas D, Rodda S, Campbell B, Logsdon M (2007) Effects of landuse change on the hydrologic regime of the Mae Chaem river basin, NW Thailand. J Hydrol 
334(1-2):215-230. https://doi.org/10.1016/j.jhydrol.2006.10. 012

286. Stewart JB, Finch JW (1993) Application of remote sensing to forest hydrology. J Hydrol 150(2-4):701-716. https://doi.org/ 10.1016/0022-1694(93)90132-S

287. Bhatasara S, Nyamwanza A (2018) Sustainability: a missing dimension in climate change adaptation discourse in Africa? J Integr Environ Sci 15(1):87-102. https://doi.org/10.1080/19438 $15 \times .2018 .1450766$

288. Lim J, Choi M (2015) Assessment of water quality based on Landsat 8 operational land imager associated with human activities in Korea. Environ Monit Assess 187(6):384. https:// doi.org/10.1007/s10661-015-4616-1

289. Deus D, Gloaguen R, Krause P (2013) Water balance modeling in a semi-arid environment with limited in situ data using remote sensing in lake Manyara, East African Rift, Tanzania. Remote Sens 5(4):10. https://doi.org/10.3390/rs5041651

290. Finch JW (1997) Monitoring small dams in semi-arid regions using remote sensing and GIS. J Hydrol 195(1):335-351. https:// doi.org/10.1016/S0022-1694(96)03228-3

291. Gangodagamage C, Clarke AC, Aggarwal SP (2001) Hydrological modeling using remote sensing and Gis. Paper presented at the 22nd Asian conference on remote sensing, Singapore, 5-9 November 2001

292. Evans H-C (2015) Climate-change awareness and online media in Zimbabwe: opportunities lost? In: Halvorsen T, Ibsen, Hilde (eds) Knowledge for a sustainable world: a Southern AfricanNordic contribution. Illustrated, reprint edn. African Minds, $p$ 163

293. Nyoni K, Kaseke E, Shoko M (2013) Assessing the presence or absence of climate change signatures in the Odzi sub-catchment of Zimbabwe. Am J Clim Change 2(04):225

294. Shadeed S, Almasri M (2010) Application of GIS-based SCSCN method in West Bank catchments. Palestine Water Sci Eng 3(1):1-13. https://doi.org/10.3882/j.issn.1674-2370.2010.01. 001

295. Helmschrot J, Flügel W-A (2002) Land use characterisation and change detection analysis for hydrological model parameterisation of large scale afforested areas using remote sensing. Phys Chem Earth Parts A/B/C 27(9-10):711-718. https://doi. org/10.1016/S1474-7065(02)00055-4

296. Shalaby A, Tateishi R (2007) Remote sensing and GIS for mapping and monitoring land cover and land-use changes in the Northwestern coastal zone of Egypt. Appl Geogr 27(1):28-41. https://doi.org/10.1016/j.apgeog.2006.09.004

297. Sibanda M, Murwira A (2012) The use of multi-temporal MODIS images with ground data to distinguish cotton from maize and sorghum fields in smallholder agricultural landscapes of Southern Africa. Int J Remote Sens 33(16):4841-4855. https://doi.org/ $10.1080 / 01431161.2011 .635715$

298. Adam EO, Elbasit MA, Solomon T, Ahmed F (2017) Integration of satellite rainfall data and curve number method for runoff estimation under semi-arid wadi system. Int Arch Photogram Remote Sens Spat Inf Sci 42

299. du Plessis A, Harmse T, Ahmed F (2015) Predicting water quality associated with land cover change in the Grootdraai Dam catchment. South Africa Water Int 40(4):647-663. https://doi. org/10.1080/02508060.2015.1067752

300. Haggard WH (1972) Meteorological satellite data. Ann N Y Acad Sci 187(1):343-349. https://doi.org/10.1111/j.1749-6632.1972. tb48340.x

301. Abd Elbasit MAM, Adam EO, Abu-Taleb K, Ahmed F, Yasuda H, Ojha CSP (2017) Space-borne rainfall measurement over arid regions. In: Sustainable water resources management. American Society of Civil Engineers, USA. https://doi.org/10.1061/ 9780784414767.ch08
302. Singh D, Rai SP, Rai D (2019) Application of geospatial techniques in hydrological modelling. In: Sustainable green technologies for environmental management. Springer, pp 167-173

303. Knudsen J, Thomsen A, Refsgaard JC (1986) WATBAL: a semidistributed, physically based hydrological modelling system. Hydrol Res 17(4-5):347-362. https://doi.org/10.2166/nh.1986. 0026

304. Vörösmarty CJ, Moore B (1991) Modeling basin-scale hydrology in support of physical climate and global biogeochemical studies: an example using the Zambezi River. Surv Geophys 12(1-3):271-311. https://doi.org/10.1007/BF01903422

305. Love D, Uhlenbrook S, Corzo-Perez G, Twomlow S, van der Zaag $P(2001)$ Rainfall interception, evaporation and runoff relationships in a semi-arid catchment, northern Limpopo basin. Zimbabwe Hydrol Sci J 55(5):687-703. https://doi.org/10.1080/ 02626667.2010.494010

306. Gumindoga W, Rwasoka DT, Nhapi I, Dube T (2015) Ungauged runoff simulation in Upper Manyame Catchment, Zimbabwe: application of the HEC-HMS model. Phys Chem Earth

307. Gumindoga W, Rwasoka DT, Timothy D (2018) Effect of landcover/land-use changes on water availability in and around Ruti Dam in Nyazvidzi catchment. Zimbabwe Water SA 44(1):136-145. https://doi.org/10.4314/wsa.v44i1.16

308. Mazvimavi D (2003) Estimation of flow characteristics of ungauged catchments: case study in Zimbabwe. Wageningen Universiteit, Wageningen

309. Alley WM (1984) On the treatment of evapotranspiration, soil moisture accounting, and aquifer recharge in monthly water balance models. Water Resour Res 20(8):1137-1149. https:// doi.org/10.1029/WR020i008p01137

310. Pitman WV (1978) Flow generation by catchment models of differing complexity - a comparison of performance. J Hydrol 38(1):59-70. https://doi.org/10.1016/0022-1694(78)90132-4

311. Rwasoka DT, Gumindoga W, Gwenzi J (2011) Estimation of actual evapotranspiration using the surface energy balance system (SEBS) algorithm in the Upper Manyame catchment in Zimbabwe. Phys Chem Earth 36:736-746

312. Gumindoga W, Rwasoka DT, Murwira A (2011) Simulation of streamflow using TOPMODEL in the Upper Save River catchment of Zimbabwe. Phys Chem Earth Parts A/B/C 36(1415):806-813. https://doi.org/10.1016/j.pce.2011.07.054

313. Sibanda T, Nonner JC, Uhlenbrook S (2009) Comparison of groundwater recharge estimation methods for the semi-arid Nyamandhlovu area. Zimbabwe Hydrogeol J 17(6):1427-1441. https://doi.org/10.1007/s10040-009-0445-z

314. Masimba O, Gumindoga W, Mhizha A, Rwasoka DT (2019) An assessment of baseline and downscaled projected climate variables in the Upper Manyame sub-catchment of Zimbabwe. Phys Chem Earth Parts A/B/C 114:102788. https://doi.org/10. 1016/j.pce.2019.07.001

315. Love $D$, Taigbenu $A E$, Jonker $L$ (2005) An overview of the Mzingwane Catchment, Zimbabwe (PN17)

316. Makungo R, Odiyo JO, Ndiritu JG, Mwaka B (2010) Rainfall - runoff modelling approach for ungauged catchments: a case study of Nzhelele River sub-quaternary catchment. Phys Chem Earth Parts A/B/C 35(13):596-607. https://doi.org/10.1016/j.pce.2010. 08.001

317. Sawunyama T, Senzanje A, Mhizha A (2006) Estimation of small reservoir storage capacities in Limpopo River Basin using geographical information systems (GIS) and remotely sensed surface areas: case of Mzingwane catchment. Phys Chem Earth Parts A/B/C 31(15-16):935-943. https://doi.org/10.1016/j.pce. 2006.08.008

318. Kibena J, Nhapi I, Gumindoga W (2014) Assessing the relationship between water quality parameters and changes in landuse 
patterns in the Upper Manyame River, Zimbabwe. Phys Chem Earth 67-69:153-163

319. Munamati M, Nyagumbo I (2010) In situ rainwater harvesting using dead level contours in semi-arid southern Zimbabwe: insights on the role of socio-economic factors on performance and effectiveness in Gwanda District. Phys Chem Earth Parts A/B/C 35(13):699-705. https://doi.org/10.1016/j.pce.2010.07. 029

320. Nyamadzawo G, Wuta M, Nyamangara J, Gumbo D (2013) Opportunities for optimization of in-field water harvesting to cope with changing climate in semi-arid smallholder farming areas of Zimbabwe. Springerplus 2(1):100. https://doi.org/10. 1186/2193-1801-2-100

321. Lorup JK, Refsgaard JC, Mazvimavi D (1998) Assessing the effect of land use change on catchment runoff by combined use of statistical tests and hydrological modelling: case studies from Zimbabwe. J Hydrol 205(3):147-163. https://doi.org/10.1016/ S0168-1176(97)00311-9

322. Manyeruke C, Hamauswa S, Mhandara L (2013) The effects of climate change and variability on food security in Zimbabwe: a socio-economic and political analysis

323. Masanganise J, Chipindu B, Mhizha T, Mashonjowa E (2012) Model prediction of maize yield responses to climate change in north-eastern Zimbabwe. Afr Crop Sci J 20(Suppl. 2):505-515

324. Svotwa $E$, Hamudikuwanda H, Makarau A (2007) Influence of climate and weather on cattle production semi-arid communal areas of Zimbabwe. Elec J Env Agric Food Chem 6:1838-1850

325. Matarira CH, Makadho JM, Mwamuka FC (1995) Zimbabwe: climate change impacts on maize production and adaptive measures for the agricultural sector. Interim report on climate change country studies. US country studies program, Washington, $\mathrm{DC}$

326. Patt A (2001) Understanding uncertainty: forecasting seasonal climate for farmers in Zimbabwe. Risk Decis Policy 6(2):105119. https://doi.org/10.1017/s1357530901000321

327. Mutekwa VT (2009) Climate change impacts and adaptation in the agricultural sector: the case of smallholder farmers in Zimbabwe. J Sustain Dev Africa 11(2):237-256

328. Zinyengere N, Mhizha T, Mashonjowa E, Chipindu B, Geerts $S$, Raes D (2011) Using seasonal climate forecasts to improve maize production decision support in Zimbabwe. Agric For Meteorol 151(12):1792-1799

329. Unganai L (2009) Adaptation to climate change among agropastoral systems: case for Zimbabwe. IOP Conf Ser Earth Environ Sci 6(41):412045

330. Love D, Uhlenbrook S, Madamombe E, Twomlow S, Zaag P (2006) An evaluation of climate and runoff variability and associated livelihood risks in the Mzingwane Catchment Limpopo Basin Zimbabwe

331. Chemura A, Kutywayo D, Chidoko P, Mahoya C (2016) Bioclimatic modelling of current and projected climatic suitability of coffee (Coffea arabica) production in Zimbabwe. Reg Environ Change 16(2):473-485

332. Marshall BE (2012) Does climate change really explain changes in the fisheries productivity of Lake Kariba (Zambia-Zimbabwe)? Trans R Soc South Africa 67(1):45-51

333. Booth TH, Stein JA, Hutchinson MF, Nix HA (1990) Identifying areas within a country climatically suitable for particular tree species: an example using Zimbabwe. Int Tree Crops J 6(1):1-16

334. Gandiwa E, Zisadza P (2010) Wildlife management in Gonarezhou National Park, southeast Zimbabwe: climate change and implications for management. Nat Faune 25(1):95-104

335. Torr SJ, Hargrove JW (1999) Behaviour of tsetse (Diptera: Glossinidae) during the hot season in Zimbabwe: the interaction of micro-climate and reproductive status. Bull Entomol Res 89(4):365-379

336. Gunda R, Chimbari MJ, Shamu S, Sartorius B, Mukaratirwa S (2017) Malaria incidence trends and their association with climatic variables in rural Gwanda, Zimbabwe, 2005-2015. Malaria J 16(1):1-13

337. Chikodzl D, Mutowo G (2014) Analysis of climate change signatures on micro-catchments as a means of understanding drying up of wetlands: the case of mutubuki wetland in gutu district of Zimbabwe. Ethiopian J Environ Stud Manag 7(2):821831. https://doi.org/10.4314/ejesm.v7i2.2S

338. Chapungu L, Nhamo $L$ (2016) An assessment of the impact of climate change on plant species richness through an analysis of the Normalised Difference Water Index (NDWI) in Mutirikwi Sub-catchment. Zimbabwe South African J Geom 5(2):244

339. Williams B, Rogers D, Staton G, Ripley B, Booth T (1994) Statistical modelling of georeferenced data: mapping tsetse distributions in Zimbabwe using climate and vegetation data. In: Modelling vector-borne and other parasitic diseases, pp 267-280

340. Matawa F, Murwira KS, Shereni W (2013) Modelling the distribution of suitable Glossina spp. habitat in the north western parts of Zimbabwe using remote sensing and climate data. Geoinform Geostast Overv 1-9

341. Sibanda S (2018) An assessment of the impacts of climate and land use/cover changes on wetland extent within Mzingwane catchment, Zimbabwe. Thesis, University of the Witwatersrand, Johannesburg, South Africa

342. Hartman J, Ebi K, McConnell KJ, Chan N, Weyant J (2002) Climate suitability: for stable malaria transmission in Zimbabwe under different climate change scenarios. Global Change Hum Health 3(1):42

343. Mugandani R, Wuta M, Makarau A, Chipindu B (2012) Reclassification of agro-ecological regions of Zimbabwe in conformity with climate variability and change. Afr Crop Sci J 20(2):361-369

344. Phillips JG, Deane D, Unganai L, Chimeli A (2002) Implications of farm-level response to seasonal climate forecasts for aggregate grain production in Zimbabwe. Agric Syst 74(3):351-369

345. Kutywayo D, Chemura A, Kusena W, Chidoko P, Mahoya C, Doucet $D$ (2013) The impact of climate change on the potential distribution of agricultural pests: the case of the coffee white stem borer (Monochamus leuconotus P.) in Zimbabwe. PLoS ONE 8(8):e73432

346. Dube T, Moyo P, Ndlovu S, Phiri K (2017) Towards a framework for the integration of traditional ecological knowledge and meteorological science in seasonal climate forecasting: the case of smallholder farmers in Zimbabwe. J Hum Ecol 54(1):49-58

347. Dube T, Intauno S, Moyo P, Phiri K (2017) The gender-differentiated impacts of climate change on rural livelihoods labour requirements in southern Zimbabwe. J Hum Ecol 58(1-2):48-56

348. Bossuet JD, Thierfelder C (2019) A perfect storm: climate change jeopardizes food security in Malawi, Zambia and Zimbabwe

349. Magadza CHD (2011) Indications of the effects of climate change on the pelagic fishery of Lake Kariba, Zambia-Zimbabwe. Lakes Reserv Res Manag 16(1):15

350. Descheemaeker K, Zijlstra M, Masikati P, Crespo O, Tui S-K (2018) Effects of climate change and adaptation on the livestock component of mixed farming systems: a modelling study from semi-arid Zimbabwe. Agric Syst 159:282-295

351. Mashonjowa E, Ronsse F, Milford JR, Pieters JG (2013) Modelling the thermal performance of a naturally ventilated greenhouse in Zimbabwe using a dynamic greenhouse climate model. Sol Energy 91:381-393 
352. Mberego S, Sanga-Ngoie K (2014) Using locally captured climatic information for guiding local-level agriculturalists in Africa: a case study of Makonde district in Zimbabwe. J Land Use Sci 9(2):178-194

353. Matarira CH, Mwamuka FC (1996) Vulnerability of Zimbabwe forests to global climate change. Climate Res 6(2):135

354. Rurinda J, Mapfumo P, van Wijk MT, Mtambanengwe F, Rufino MC, Chikowo R, Giller KE (2014) Sources of vulnerability to a variable and changing climate among smallholder households in Zimbabwe: a participatory analysis. Clim Risk Manag 3:65-78

355. Chifamba E, Mashavira N (2011) Adaption and mitigation strategies in sustainable land resource management to combat the effects of climate change in Chipinge, Zimbabwe. J Sustain Dev Africa 13(2):15-27

356. Mudombi-Rusinamhodzi G, Siziba S, Kongo V (2012) Factors affecting smallholder farmers' responsiveness to climate variability induced hazards in Zimbabwe. Afr Crop Sci J 20(Suppl. 2):297-301

357. Nhemachena C, Mano R, Mudombi S, Muwanigwa V (2014) Climate change adaptation for rural communities dependent on agriculture and tourism in marginal farming areas of the Hwange District. Zimbabwe Afr J Agric Res 9(26):2045-2054

358. Mbereko A, Chimbari MJ, Mukaratirwa S (2018) The political ecology of stakeholder-driven climate change adaptation: case study from Ntalale ward, Gwanda district, in Zimbabwe. Jàmbá J Disast Risk Stud 10(1):1-10

359. Musarandega $\mathrm{H}$, Chingombe W, Pillay R (2018) Harnessing local traditional authorities as a potential strategy to combat the vagaries of climate change in Zimbabwe. Jàmbá J Disast Risk Stud 10(1):1-6

360. Chanza N, Chigona A, Nyahuye A, Mataera-Chanza L, Mundoga T, Nondo N (2019) Diagnosing barriers to climate change adaptation at community level: reflections from Silobela. Zimbabwe GeoJournal 84(3):771-783

361. Mushawemhuka W, Rogerson JM, Saarinen J (2018) Naturebased tourism operators' perceptions and adaptation to climate change in Hwange National Park. Zimbabwe Bull Geogr Socio-econ Ser 42(42):115-127. https://doi.org/10.2478/ bog-2018-0034

362. Jiri O, Mafongoya PL, Chivenge P (2017) Building climate change resilience through adaptation in smallholder farming systems in semi-arid Zimbabwe. Int J Clim Change Strateg Manag 9(2):151-165

363. Jiri O, Mafongoya PL, Leal Filho W (2018) Managing vulnerability to drought and enhancing smallholder farmers resilience to climate change risks in Zimbabwe. In: Leal Filho (ed) Handbook of climate change resilience, pp 1-17

364. Katsaruware-Chapoto RD, Mafongoya PL, Gubba A (2017) Farmer knowledge of climate change impacts and adaptation strategies in the management of vegetable insect pests in Zimbabwe. J Agric Sci 9(12):194

365. Mutandwa E, Hanyani-Mlambo B, Manzvera J (2019) Exploring the link between climate change perceptions and adaptation strategies among smallholder farmers in Chimanimani district of Zimbabwe. Int J Soc Econ 46(7):850-860

366. Simba F, Chikodzi D, Murwendo T (2012) Climate change scenarios, perceptions and crop production: a case study of Semi-arid Masvingo Province in Zimbabwe. J Earth Sci Climate Change 3(124):2

367. Nyahunda L, Tirivangasi HM (2019) Challenges faced by rural people in mitigating the effects of climate change in the Mazungunye communal lands, Zimbabwe. Jàmbá J Disast Risk Stud 11(1):1-9

368. Nyahunda L, Matlakala FK, Makhubele JC (2019) Role of social workers in mitigating the effects of climate change in makonde communal lands. Zimbabwe e-BANGI J 16(9):172

369. Zinyemba C, Archer E, Rother H-A, Gent D (2018) Climate variability, perceptions and political ecology: factors influencing changes in pesticide use over 30 years by Zimbabwean smallholder cotton producers. PLoS ONE 13(5):e0196901

370. Chanza N (2017) Limits to climate change adaptation in zimbabwe: insights, experiences and lessons. Limits Clim Change Adapt. https://doi.org/10.1007/978-3-319-64599-5_6

Publisher's Note Springer Nature remains neutral with regard to jurisdictional claims in published maps and institutional affiliations. 